\title{
Elements Of Governance Of The Management Of Private Stadiums (Artificial Turf) To Control The Dangers Of Their Spread In The Arab Republic Of Egypt \\ Prof. Dr. Rehab Ali Amin Othman
}

Research Problem and Importance:

Governance is one of the most important topics in the modern institutions and organizations, which has increased attention in recent years as a result of the tendency of many countries in the world to shift to economic systems.

Ibrahim Al-Essawi Ibrahim (2003), Jalal Al-Hussein (2015) and CIPE (2018) agreed that governance plays a role in enhancing the competitiveness of the economy, attracting investments and supporting economic performance and competitiveness. (23: 36) (26: 30) (15:2)

Abdullah Abdullatif Abdullah (2017) defines governance as a set of laws, rules, regulations, standards and procedures aimed at regulating the nature of the relationship between project management and beneficiaries to achieve performance excellence. (3:11)

There is no agreed general definition of sports governance, defined by the Australian Sports Commission (2004) as the structures and processes used by sports organizations to set their strategic goals and monitor their performance against these goals. (11: 14)

The Australian Sports Commission (2011) states that guidelines and resources should be developed to help sport organizations implement and evaluate their governance.As such, the Australian Sports Commission has developed a set of governing ingredients for local sports organizations, including legal, human, physical, informational, technical, and administrative. (12:9).

The researcher relied on these elements of governance to form the basis of the questionnaire set out in the research procedures.

According to Ibrahim Marzouk Mohamed (2002) and Tarek Abdel-Al Hammad (2007), in order to support the implementation of governance, we must work to classify the risks that can occur and try to manage and control, where the main cause of the phenomenon of risks is the great development in various aspects of life where dangers to the organization has increased. (24:38) (44:21)

The results of the studies confirm that there are many risks facing the sports organizations such as the study of Adel Kamal al-Din Ali (2015) (5) and the study of Mohammed Saad Mohamed Abdel Kader (2015) (34) and the study of Aladdin Mohammed Sayed (2012) (9) study of Ezzedine Darwish Muhammad Ahmad (2012) (17) The most important results of which were the existence of risks related to sports facilities, and risks related to security and safety, and risks associated with the lack of regulations threatening the entity of sports institutions.

A new phenomenon has emerged in Egypt known as the private stadiums (artificial turf) which is considered one of the important sports institutions in our society that provide many sports and social services and activities.Mohammed Sobhy Hassan (2019) stressed that it is considered one of the basic aspects that support the sports system and bears a heavy burden of the country's obligation $(35: 2)$

FIFA confirmed that the stadiums should be subjected to several tests based on obtaining certified certificates confirming that the stadium conforms to the conditions in terms of efficiency and shock resistance. (66) 
The International Agency for Research on Cancer (IARC) has pointed out that artificial turf has carbon black as a component, which is classified as a carcinogen, in addition to benzothiazole, a toxic substance when exposed to high temperature and causes constant skin itching. (68)

The Daily Mail, cited by Al-yoom Al-Sabee (2018), confirmed that 50 football players at the University of Washington had leukemia as a result of dangerous ingredients found in the artificial turf that cause skin and lung cancer. (47)

According to the official website Masrawy (2016), which confirmed the injury of player Karim Abdel Hadi in his ankle ligaments during a football match in a private stadium and it turned out that the injury was caused mainly by playing on a poor pitch that does not conform to the standards. (48)

In this regard, the researcher conducted an open personal interview with Dr. Mahmoud Mohamed Omar, founder and advisor of the National Center for Toxicology, and Dr. Khaled Hassan Ahmed, director of Al-Amaal Center for Physical Nutrition and Treatment in order to identify the dangers of private stadiums (artificial turf) where they stressed that it contains petrochemicals that leads to injury of many health problems as the constant friction with the grass occurs as a result of corrosion resulting in problems in the respiratory system, liver, kidneys and nervous system.

Decisions were issued to remove (2266) stadiums on an area of (694) acres and (2) carats of agricultural land, where the Ministry of Agriculture sent a memorandum to the Ministry of Local Development to direct the governors to quickly issue the removal decisions in coordination between localities and agricultural directorates to restore the land to protect the agricultural area. (36: 2) (67) (11)

Also, many lawsuits of private stadiums (artificial turf) have been made because of the negative impact on the neighborhood's inhabitants of noise, riots and weak electricity as a result of population density, severe poor service and lack of nets on the walls of the stadiums.

In the light of these multiple dangers caused by the spread of the private stadiums in the Arab Republic of Egypt, the researcher believes that one should look for ways to face and reduce these risks. We should seek to apply the governance in the private stadiums through which a set of controls can contribute in enhancing competitiveness.

In light of the above, the researcher conducted a first exploratory study on a random sample of (12) responsible for the private stadiums (artificial turf) and the results of the agreement shows (70\%) that the risks faced by them when managing the private stadiums (artificial turf) near the stadiums from each other in the same area, the difficulty of obtaining licenses for the stadium, and agreed $(80 \%)$ that the risks are faced in various ways, including the provision of offereing the best possible services, alert to take the care and attention to provide security and safety.

The researcher also conducted a second exploratory study on a random sample of (8) players practicing playing on the private stadiums (artificial turf) and the results of the agreement $(70 \%)$ shows that the dangers faced by players when practicing activity on the private stadiums (artificial turf) used, caused many injuries at times, lack of tools and equipment, low level of experience in management, lack of interest in the pitch of the stadium, the owners control the pricing of renting these stadiums and there is no fixed prices are adhered to, as agreed (100\%) that there are no steps taken to reduce 
the risk of private stadiums.

The researcher reviewed recent studies on organization governance, including Glasgow and Daved. B. (2008) (20), Ibrahim Mohammed Abu Saada (2009) (25), Lubna, Aram, Bashiti (2009) (13), Salem Said Baajajah (2009) (40), Fatima Fahad Khalil Al-Muzain (2017) (19) , Ezzedine Darwish Mohamed Ahmed (2012) (17), Mohamed Saad Mohamed Abdelkader (2015) (34). The studies are all linked to the subject of the research and most of their results emphasized the importance of governance and its role in facing problems and risks and improving the level of performance.

In light of the above, the researcher addressed the subject of the research and its title

"The Elements of Governance of the Management of Private stadiums (Artificial Turf) to Control the Dangers of Their Spread in the Arab Republic of Egypt" Research Objective:

The research aims to identify the elements of governance of the management of private stadiums (artificial turf) to control the risks of it's spread in the Arab Republic of Egypt by identifying:

- The current status of governance of the risks of the spread of private stadiums (artificial turf) in the Arab Republic of Egypt.

- The reasons for the spread of private stadiums (artificial turf) in the Arab Republic of Egypt.

- Risks resulting from the spread of private stadiums (artificial turf) in the Arab

Republic of Egypt.

Research Questions:

- What is the current status of governance of the dangers of the spread of private stadiums (artificial turf) in the Arab Republic of Egypt?

- What are the reasons for the spread of private stadiums (artificial turf) in the Arab Republic of Egypt?

- What are the risks resulting from the spread of private stadiums (artificial turf) in the Arab Republic of Egypt?

Research procedures:

Research Methodology:

The researcher used the descriptive survey method to suit the nature of the research.

Population and Sample Research:

- Research population :

A number of (31) private stadiums (artificial turf) were randomly selected from the governorates of the Arab Republic of Egypt.

\section{- Research sample:}

Due to the difficulty of getting comprehensive data of the elements of the research population, where there are no official statistics for the private stadiums (artificial turf) at the level of the Arab Republic of Egypt because it is not subject to any control point, the researcher relied on a simple random sampling method and thus became the main research sample (298) individual, individual and divided as follows (sample of the owners of the stadiums (artificial turf), sample of employees of the private stadiums (artificial turf), sample of officials in the concerned authorities (Ministry of Youth and Sports - Directorate of Youth and Sports - Syndicate of Sports

Professions), a random sample of beneficiaries of the activity in the private stadiums (artificail turf). 


\section{Data Collection Tools:}

Interview, documents, records, questionnaire where the researcher designed three questionnaire forms.

\section{Scientific transactions to codify the three questionnaire forms:}

\section{First: Validity:}

Validity of the content of the three questionnaires:

The researcher presented the statements of the axes and dimensions of the three questionnaire forms to the experts, the researcher made the edits according to their opinions and agreed with a rate ranging between $(66.67: 100 \%)$ with the researcher taking $(66 \%)$ to accept the statements.

The validity of the internal consistency coefficient for the three questionnaire statements:

The researcher used the method of internal consistency and is illustrated in Table (1: 6).

\section{Validity of the first form (The owners and staff of the stadiums):}

Table (1) Correlation coefficients between the axes of the questionnaire of the group (The owners and stadium staff $)(n=11)$

\begin{tabular}{|c|c|c|c|c|c|c|}
\hline Axes & & rst axis & sixa dnoceS & \multicolumn{2}{|l|}{ Third axis } & otal score \\
\hline First axis & & & 0.767 & 0.760 & \multicolumn{2}{|r|}{0.877} \\
\hline sixa dnoces & & & & 0.767 & \multicolumn{2}{|r|}{0.715} \\
\hline Third axis & & & & & \multicolumn{2}{|r|}{0.705} \\
\hline \multicolumn{7}{|c|}{ Questionnaire total score } \\
\hline \multicolumn{7}{|c|}{$\begin{array}{l}\text { Value of } \operatorname{Rg}(9,0.05)=0.602 \\
\text { Table (2) Correlation coefficients between the dimensions of the first axis of the group (owners } \\
\text { and stadium staff) }(n=11)\end{array}$} \\
\hline Axes & $\begin{array}{l}\text { First } \\
\text { dim. }\end{array}$ & $\begin{array}{l}\text { Second } \\
\text { dim. }\end{array}$ & $\begin{array}{l}\text { Third } \\
\text { dim. }\end{array}$ & $\begin{array}{l}\text { Fourth } \\
\text { dim. }\end{array}$ & $\begin{array}{l}\text { Total } \\
\text { score of } \\
\text { the axis }\end{array}$ & $\begin{array}{l}\text { Question. } \\
\text { total score }\end{array}$ \\
\hline First dimension & & 0.698 & 0.705 & 0.713 & 0.732 & 0.723 \\
\hline Second dimension & & & 0.847 & 0.790 & 0.735 & 0.800 \\
\hline Third dimension & & & & 0.758 & 0.767 & 0.768 \\
\hline Fourth dimension & & & & & 0.729 & 0.808 \\
\hline Total score of the axis & & & & & & 0.715 \\
\hline estionnaire total score & & & & & & \\
\hline
\end{tabular}

Value of $\operatorname{Rg}(9,0.05)=0.602$

Tables $(1,2)$ shows the existence of a correlation statistically significant at the level of significance (0.05) between the degree of each axis and between axes and between the total score, and also between each dimension and the total score for each axis and the total score of the questionnaire, which shows the validity of the internal consistency of the initial questionnaire . 


\section{Validation of the second form (The officials in the concerned authorities)}

Table (3): Correlation coefficients between the axes of the questionnaire for the group (The officials in the concerned authorities $)(n=10)$

\begin{tabular}{ccccc}
\hline Axes & First axis & sixa dnoceS & Third axis & Total score \\
\hline First axis & & 0.685 & 0.720 & 0.810 \\
\hline xa dnoceSsi & & 0.804 & 0.742 \\
\hline Third axis & & & 0.887 \\
\hline Questionnaire total score & & & \\
\hline
\end{tabular}

\section{Value of $\operatorname{Rg}(8,0.05)=0.632$}

Table (4): Correlation coefficients between the dimesnsions of the first axis for the group (The officials in the concerned authorities $)(n=10)$

\begin{tabular}{|c|c|c|c|c|c|c|}
\hline Axes & $\begin{array}{l}\text { First } \\
\text { dim. }\end{array}$ & $\begin{array}{c}\text { Second } \\
\text { dim. }\end{array}$ & $\begin{array}{l}\text { Third } \\
\text { dim. }\end{array}$ & $\begin{array}{c}\text { Fourth } \\
\text { dim. }\end{array}$ & $\begin{array}{c}\text { Total } \\
\text { score of } \\
\text { the axis }\end{array}$ & $\begin{array}{l}\text { Question. } \\
\text { total score }\end{array}$ \\
\hline First dimension & & 0.757 & 0.802 & 0.794 & 0.759 & 0.704 \\
\hline Second dimension & & & 0.759 & 0.770 & 0.804 & 0.680 \\
\hline Third dimension & & & & 0.850 & 0.780 & 0.760 \\
\hline Fourth dimension & & & & & 0.760 & 0.761 \\
\hline Total score of the axis & & & & & & 0.751 \\
\hline Questionnaire total score & & & & & & \\
\hline
\end{tabular}

Value of $\operatorname{Rg}(8,0.05)=0.632$

Tables $(3,4)$ shows the existence of a correlation statistically significant at the level of significance (0.05) between the degree of each axis and between axes and between the total score, and also between each dimension and the total score for each axis and the total score of the questionnaire, which indicates the validity of the internal consistency of the questionnaire the second.

\section{Validation of the third form (beneficiaries):}

Table (5) Correlation coefficients between the axes of the questionnaire for the group (The beneficiaries) $(n=25)$

\begin{tabular}{ccccc}
\hline Axes & First axis & sixa dnoceS & Third axis & Total score \\
\hline First axis & & $\mathbf{0 . 6 3 4}$ & $\mathbf{0 . 8 3 7}$ & $\mathbf{0 . 6 5 2}$ \\
\hline sixa dnoceS & & $\mathbf{0 . 5 0 7}$ & $\mathbf{0 . 6 5 8}$ \\
\hline Third axis & & & $\mathbf{0 . 4 8 7}$ \\
\hline Questionnaire total score & & & \\
\hline
\end{tabular}

Value of $\operatorname{Rg}(23,0.05)=0.396$

Table (6) Correlation coefficients between the dimensions of the first axis for the group (The beneficiaries $)(n=25)$

\begin{tabular}{|c|c|c|c|c|c|c|}
\hline Axes & $\begin{array}{l}\text { First } \\
\text { dim. }\end{array}$ & $\begin{array}{l}\text { Second } \\
\text { dim. }\end{array}$ & $\begin{array}{l}\text { Third } \\
\text { dim. }\end{array}$ & $\begin{array}{l}\text { Fourth } \\
\text { dim. }\end{array}$ & $\begin{array}{l}\text { Total score } \\
\text { of the axis }\end{array}$ & $\begin{array}{c}\text { Question. } \\
\text { total } \\
\text { score }\end{array}$ \\
\hline First dimension & & 0.604 & 0.542 & 0.683 & 0.427 & 0.517 \\
\hline Second dimension & & & 0.670 & 0.437 & 0.515 & 0.777 \\
\hline Third dimension & & & & 0.399 & 0.470 & 0.410 \\
\hline Fourth dimension & & & & & 0.604 & 0.777 \\
\hline Total score of the axis & & & & & & 0.460 \\
\hline $\begin{array}{l}\text { Questionnaire total } \\
\text { score }\end{array}$ & & & & & & \\
\hline
\end{tabular}

Value of $\operatorname{Rg}(23,0.05)=0.396$ 
Table $(5,6)$ shows a statistically significant correlation at a significant level $(0.05)$ between the degree of each axis and between the axes and between the total score, and between each dimension and between the total score for each axis and the total score of the questionnaire, which shows the validity of the internal consistency of the third questionnaire.

Second: Stability: Stability was found in two ways:

Stability of the first form (The owners and stadiums staff):

Table (7) Stability of the questionnaire by the Split-Half and alpha-Kronbach methods for the group (The owners and staff of the stadiums) $(n=11)$

\begin{tabular}{|c|c|c|c|}
\hline \multirow[b]{2}{*}{ Axes and dimensions } & \multicolumn{2}{|c|}{ Split-Half } & \multirow{2}{*}{$\begin{array}{c}\text { alpha- } \\
\text { Kronbac } \\
\text { h } \\
\end{array}$} \\
\hline & $\begin{array}{l}\text { Spearman } \\
\text { Brown }\end{array}$ & Getman & \\
\hline $\begin{array}{l}\text { The first axis (Identifying the current status of the governance of the } \\
\text { risks of the spread of private stadiums (artificial turf) in the Arab } \\
\text { Republic of Egypt) }\end{array}$ & 0.753 & 0.741 & 0.763 \\
\hline The first dimension (Administrative components) & 0.736 & 0.747 & 0.746 \\
\hline The second dimension (Legal components) & 0.711 & 0.763 & 0.721 \\
\hline The third dimension (Financial, human and informatics components) & 0.750 & 0.780 & 0.760 \\
\hline The fourth Dimension (Technical components) & 0.814 & 0.735 & 0.824 \\
\hline $\begin{array}{c}\text { The second axis (Reasons for the spread of private stadiums } \\
\text { (artificial turf) in the Arab Republic of Egypt) }\end{array}$ & 0.905 & 0.761 & 0.915 \\
\hline $\begin{array}{l}\text { The third axis (Risks of the spread of private stadiums (artificial turf) } \\
\text { in the Arab Republic of Egypt) }\end{array}$ & 0.744 & 0.782 & 0.771 \\
\hline Questionnaire total score & 0.751 & 0.734 & 0.854 \\
\hline
\end{tabular}

It is clear from Table (7) that the coefficient of stability by the split-half method ranged between (0.711) and (0.905), and that the stability of the Alpha Kronbach ranged between (0.721) and (0.915), which indicates that the first questionnaire under consideration has a high coefficient of stability.

Stability of the second form (The officials in the concerned authorities):

Table (8) Stability of the questionnaire by the split-half and alpha-Kronbach methods for the group (The officials in the concerned authorities) $(n=10)$

\begin{tabular}{|c|c|c|c|}
\hline \multirow[b]{2}{*}{ Axes and dimensions } & \multicolumn{2}{|c|}{ Split-Half } & \multirow[b]{2}{*}{$\begin{array}{l}\text { alpha- } \\
\text { Kronbach }\end{array}$} \\
\hline & $\begin{array}{c}\text { Spearman } \\
\text { Brown }\end{array}$ & Getman & \\
\hline $\begin{array}{l}\text { The first axis (Identifying the current status of the governance of the risks of the } \\
\text { spread of private stadiums (artificial turf) in the Arab Republic of Egypt) }\end{array}$ & 0.770 & 0.763 & 0.808 \\
\hline The first dimension (administrative components) & 0.777 & 0.761 & 0.787 \\
\hline The second dimension (legal components) & 0.773 & 0.741 & 0.783 \\
\hline The third dimension (physical, human and informatics) & 0.798 & 0.728 & 0.780 \\
\hline Fourth Dimension (Technical Components) & 0.767 & 0.854 & 0.777 \\
\hline $\begin{array}{l}\text { The second axis (Reasons for the spread of private stadiums (artificial turf) in the } \\
\text { Arab Republic of Egypt) }\end{array}$ & 0.772 & 0.745 & 0.782 \\
\hline $\begin{array}{l}\text { The third axis (Risks of the spread of private stadiums (artificial turf) in the } \\
\text { Arab Republic of Egypt) }\end{array}$ & 0.747 & 0.725 & 0.757 \\
\hline Questionnaire total score & 0.745 & 0.828 & 0.855 \\
\hline
\end{tabular}

It is clear from Table (8) that the coefficient of stability by the split-half method ranged between (0.725) and (0.854) and that the stability factor of Alpha Kronbach ranged between (0.757) and (0.855), which indicates that the second questionnaire in question has a high coefficient of stability. 
Stability of the third questionnaire form (The beneficiaries):

Table (9) Stability of the questionnaire by split-half and alpha-Kronbach methods for the group (The beneficiaries) $(n=25)$

\begin{tabular}{|c|c|c|c|}
\hline \multirow[b]{2}{*}{ Axes and dimensions } & \multicolumn{2}{|c|}{ Split-Half } & \multirow{2}{*}{$\begin{array}{l}\text { alpha- } \\
\text { Kronbach }\end{array}$} \\
\hline & $\begin{array}{c}\text { Spearman } \\
\text { Brown }\end{array}$ & Getman & \\
\hline $\begin{array}{l}\text { The first axis (Identifying the current status of the governance of the risks of the } \\
\text { spread of private stadiums (artificial turf) in the Arab Republic of Egypt) }\end{array}$ & 0.704 & 0.756 & 0.814 \\
\hline The first dimension (administrative components) & 0.710 & 0.772 & 0.720 \\
\hline The second dimension (legal components) & 0.736 & 0.834 & 0.735 \\
\hline The third dimension (physical, human and informatics) & 0.762 & 0.752 & 0.771 \\
\hline Fourth Dimension (Technical Components) & 0.787 & 0.744 & 0.797 \\
\hline $\begin{array}{l}\text { The second axis (Reasons for the spread of private stadiums (artificial turf) in the } \\
\text { Arab Republic of Egypt) }\end{array}$ & 0.772 & 0.724 & 0.782 \\
\hline $\begin{array}{l}\text { The third axis (Risks of the spread of private stadiums (artificial turf) in the Arab } \\
\text { Republic of Egypt) }\end{array}$ & 0.705 & 0.779 & 0.746 \\
\hline Questionnaire total score & 0.775 & 0.829 & 0.795 \\
\hline
\end{tabular}

It is clear from Table (19) that the coefficient of stability by the split-half method ranged between (0.704) and (0.834) and that the stability index of Alpha Kronbach ranged between $(0.720)$ and $(0.814)$, which indicates that the third questionnaire in question has a high stability coefficient .

In the light of views of the experts and after conducting scientific transactions for the three questionnaire forms, a final copy of the questionnaire forms was reached.

Statistical Processing:

The researcher used the iterations and percentage, Pearson Correlation Coefficient, Spearman Brown Split-half, Cranach's alpha, Getman, weighting ratio, weighted average arithmetic, Chi-Square Goodness of Fit Test, Cross Tabulation 
Presentation and discussion of results

Table (10) Comparison of the results of iterations, percentages, Chi square, weighting ratio, average value and the prevailing direction of response to the first axis, first dimension (Administrative components) for every two groups

\begin{tabular}{|c|c|c|c|c|c|c|c|c|c|c|c|c|c|c|c|c|c|}
\hline \multicolumn{3}{|c|}{ State. number } & \multirow[b]{3}{*}{ Statement } & \multicolumn{7}{|c|}{$\begin{array}{l}\text { Comparison of the groups (owners, staff and officials) } \\
\end{array}$} & \multicolumn{7}{|c|}{ 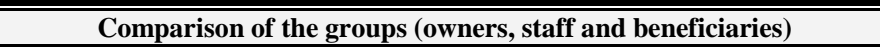 } \\
\hline \multirow[b]{2}{*}{ 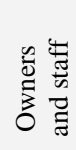 } & \multirow[b]{2}{*}{$\frac{n}{\sqrt[\pi]{0}}$} & \multirow[b]{2}{*}{ 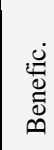 } & & \multicolumn{3}{|c|}{ Owners and staff $=150$} & \multicolumn{3}{|c|}{ Officials $=27$} & \multirow[b]{2}{*}{$\begin{array}{l}\text { Chi } \\
\text { Sq. }\end{array}$} & \multicolumn{3}{|c|}{ Owners and staff $=150$} & \multicolumn{3}{|c|}{ Beneficiaries $=121$} & \multirow[b]{2}{*}{$\begin{array}{l}\text { Chi } \\
\text { Sq. }\end{array}$} \\
\hline & & & & $\begin{array}{l}\text { Approv. } \\
\text { rate }\end{array}$ & Direct. & $\begin{array}{l}\text { Weight. } \\
\text { ratio }\end{array}$ & $\begin{array}{l}\text { Approv. } \\
\text { rate }\end{array}$ & Direct. & $\begin{array}{l}\text { Weight. } \\
\text { ratio }\end{array}$ & & $\begin{array}{l}\text { Approv. } \\
\text { rate }\end{array}$ & Direct. & $\begin{array}{l}\text { Weight. } \\
\text { ratio }\end{array}$ & $\begin{array}{l}\text { Approv. } \\
\text { rate }\end{array}$ & Direct. & $\begin{array}{l}\text { Weight. } \\
\text { ratio }\end{array}$ & \\
\hline 1 & 1 & & $\begin{array}{l}\text { A science-based plan is available to ensure the operation of } \\
\text { the private stadiums. }\end{array}$ & 46.67 & No & 73.33 & 33.33 & No & 66.67 & 1.65 & & & & & & & \\
\hline 2 & 2 & & $\begin{array}{l}\text { There is an organizational structure for all employees of } \\
\text { the private stadium (artificial turf) to determine the } \\
\text { channels of communication. }\end{array}$ & 39.33 & No & 69.67 & 37.04 & No & 68.52 & 0.05 & & & & & & & \\
\hline $3 / \mathbf{1}$ & $3 / \mathbf{1}$ & & Goals of the private stadiums. & 20.00 & No & 60.00 & $\mathbf{0 . 0 0}$ & No & 50.00 & $* 6.50$ & & & & & & & \\
\hline $3 / 2$ & $3 / 2$ & & Organizational structure of the stadiums. & 20.00 & No & 60.00 & 0.00 & No & 50.00 & $* 6.50$ & & & & & & & \\
\hline $3 / 3$ & $\mathbf{3 / 3}$ & & Different responsibilities and competencies of employees. & 20.00 & No & 60.00 & 0.00 & No & 50.00 & $* 6.50$ & & & & & & & \\
\hline 4 & 4 & & $\begin{array}{l}\text { The private stadiums (artificial turf) are under the direct } \\
\text { supervision of the Ministry of Youth and Sports. }\end{array}$ & 0.00 & No & 50.00 & 0.00 & No & 50.00 & 0.00 & & & & & & & \\
\hline 5 & 5 & 1 & $\begin{array}{l}\text { Private stadiums shall comply with the building } \\
\text { requirements and health specifications. }\end{array}$ & 86.67 & Yes & 93.33 & 29.63 & No & 64.81 & $\begin{array}{c}43.33 \\
*\end{array}$ & 86.67 & Yes & 93.33 & 15.70 & No & $\mathbf{5 7 . 8 5}$ & $\begin{array}{l}136 . \\
* 26\end{array}$ \\
\hline 6 & 6 & & $\begin{array}{l}\text { There are criteria for assessing the level of service provided } \\
\text { by private stadiums (artificial turf) by a specialized } \\
\text { committee. }\end{array}$ & 66.67 & Yes & 83.33 & 33.33 & No & 66.67 & $\begin{array}{c}10.75 \\
*\end{array}$ & & & & & & & \\
\hline 7 & & 2 & $\begin{array}{l}\text { Identify opportunities and risks that may affect future } \\
\text { activities. }\end{array}$ & & & & & & & & 86.67 & Yes & 93.33 & 15.70 & No & 57.85 & $\begin{array}{l}136 . \\
* 26\end{array}$ \\
\hline 8 & & 3 & $\begin{array}{l}\text { The department is working on identifying priorities and } \\
\text { resources to reduce the risks in the private stadiums. }\end{array}$ & & & & & & & & 16.67 & No & 58.33 & 18.18 & No & 59.09 & 0.11 \\
\hline 9 & & 4 & $\begin{array}{l}\text { Adequate health care is provided to all beneficiaries of } \\
\text { private stadiums (artificial turf). }\end{array}$ & & & & & & & & 16.67 & No & 58.33 & 18.18 & No & 59.09 & 0.11 \\
\hline 10 & & 5 & $\begin{array}{l}\text { Decisions are made according to specific, clear and stated } \\
\text { rules. }\end{array}$ & & & & & & & & 60.00 & Yes & 80.00 & 17.36 & No & 58.68 & $\begin{array}{c}\mathbf{5 0 . 3} \\
* 7\end{array}$ \\
\hline 11 & & 6 & $\begin{array}{l}\text { The management of the private stadiums provides accurate } \\
\text { information to the public in a timely manner }\end{array}$ & & & & & & & & 80.00 & Yes & 90.00 & 33.88 & No & 66.94 & $\begin{array}{c}\mathbf{5 9 . 0} \\
* 6 \\
\end{array}$ \\
\hline
\end{tabular}




\begin{tabular}{c|c|c|l||}
\hline 12 & 7 & & $\begin{array}{l}\text { Commitment to maintain the use of land for what has been } \\
\text { allocated according to the local plan. }\end{array}$ \\
\hline 13 & 8 & & Physiotherapy services are not allowed in private stadiums \\
\hline 14 & 9 & & $\begin{array}{l}\text { The stadiums management shall take into account the non- } \\
\text { disturbance of the residents of the neighborhood. }\end{array}$ \\
\hline 15 & 10 & & $\begin{array}{l}\text { Demographic characteristics of the surrounding stadiums } \\
\text { should be presented along with the feasibility study of the } \\
\text { stadium when the licenses for these stadiums are allowed. }\end{array}$ \\
\hline $16 / 1$ & & 1 & The employees. \\
\hline $16 / 2$ & & 2 & Beneficiaries of the activities provided by the stadiums. \\
\hline $16 / 3$ & & 3 & 1 \\
7 & The neighborhood surrounding the private stadium. \\
\hline
\end{tabular}

\begin{tabular}{||c|c|c|c|c|c|c||}
\hline 33.33 & No & 66.67 & 25.93 & No & 62.96 & 0.58 \\
\hline 0.00 & No & 50.00 & 22.22 & No & 61.11 & $\begin{array}{c}34.50 \\
*\end{array}$ \\
\hline 86.67 & Yes & 93.33 & 0.00 & No & 50.00 & $\begin{array}{c}88.12 \\
*\end{array}$ \\
\hline 86.00 & Yes & 93.00 & 22.22 & No & 61.11 & $\begin{array}{c}51.43 \\
*\end{array}$ \\
\hline & & & & & & \\
\hline & & & & & & \\
\hline & & & & & & \\
\hline
\end{tabular}

\begin{tabular}{||c|c|c|c|c|c|c}
\hline & & & & & & \\
\hline & & & & & & \\
\hline & & & & & & \\
\hline 60.00 & Yes & 80.00 & 17.36 & No & 58.68 & $\begin{array}{c}50.3 \\
* 7\end{array}$ \\
\hline 86.67 & Yes & 93.33 & 15.70 & No & 57.85 & $\begin{array}{c}136 . \\
* 26\end{array}$ \\
\hline 16.67 & No & 58.33 & 18.18 & No & 59.09 & 0.11 \\
\hline
\end{tabular}

Value of Chi square $(1,0.05)=3.841$ Weighted average: No $(1: 1.5)$, Yes (1.6: 2$)$

All statements of the axis and its dimension except those common to the three groups will be presented and discussed in the following table.

Table (10) shows that there are statistically significant differences between the responses of the owners and stadium staff and the officials in the concerned authorities about the statements $(1,2,4,12)$ for the owners and staff of the stadiums and the corresponding statements $(1,2,4,7)$ for the officials in the concerned authorities. The responses came in an unacceptable direction ranging from $(0.00: 46.67 \%)(0.00: 37.04 \%)$

respectively and Chi came in the range of $(0.00: 1.65)$.

The study of Iman Mohamed Nasr El Gamal (2011) (16) recommends the need for structures for institutions and companies to ensure the presence of control over employees to determine financial and administrative violations and the extent of compliance with the law in the light of good governance rules.

The researcher agrees with these results as the randomness of working without a specific plan and the establishment of those stadiums that appeared without any control from any side and spread widely in record times has led to the emergence of many risks affecting the level of sports and beneficiaries.

The results of the table also showed that there are statistically insignificant differences between the responses of the two research groups on the statements $(3 / 1,3 / 2,3 / 3,13)$ to the owners and employees and the corresponding statements $(3 / 1,3 / 2,3 / 3,8)$. For officials where the responses of the two groups came in an unacceptable direction where they ranged between (0.00:20.00\%) (0.00:22.22\%), respectively, the value of Chi ranged between $(6.50 *: 34.50 *)$. 
Hassan Bashir Mohamed (2018) asserts that the organizational guide is one of the most important influences in the institutions where it is considered the identity card of the organization, a booklet that presents a summary of policies, procedures, structure, competencies and objectives of the organization. (21: 11)

The researcher agrees with the results of these statements. By interacting with the practical side, found that most of these stadiums do not have a regulatory guide which is considered as the basis on which decisions are taken.

It is also clear that there are statistically insignificant differences between the responses of the owners, employees and the officials for the statements $(6,14,15)$ for the owners and staff of the stadiums and the corresponding statements $(6,9,10)$ where the responses of the owners and employees came in an acceptable direction (66.67: 86.67). While the responses of the officials came in unacceptable direction (0.00: $33.33 \%)$ with value of Chi ranging between $(10.75 *: 88.12 *)$.

Mohsen Ahmed Al-Khudhairi (2005) and Tariq Abdul-Al-Aal Hammad (2007) emphasize that the fundamentals of governance contribute to the real picture of all what is happening in the institution, raise its performance to get more resources, determining the path of exploitation, and strengthening communication mechanisms and orientation towards efficiency in service delivery. (36: 3) (44: 110)

In the opinion of the researcher, the difference of views in these results may be due to the fact that the owners of the project always seek to highlight the highest levels in their facility and management, and the opinion of officials may be correct or incorrect because from the viewpoint of the researcher how to form an opinion on a party they do not supervise.

It is also clear from the table that there are statistically significant differences between the responses of owners, employees and beneficiaries on the statements $(8,9,16 / 3)$ corresponding $(3,4,7 / 3)$, although the responses of the two groups came in an unacceptable direction by $(16.67 \%)$ $(18.18 \%)(0.00: 37.04 \%)$ respectively. The value of Chi was $(0.11)$.

The study of Samir Ali Ibrahim (2011) (41) recommended the need to educate players on the quality of sports injuries, with the provision of medical personnel to do a medical examination throughout the period of exercise.

The researcher agrees with these results because there is no administrative text or decision requiring the owners of these stadiums to provide first aid tools and a doctor to deal with injuries that may result from practice and play.

It is also clear that there are statistically insignificant differences between the responses of the owners and employees group and the beneficiaries on the statements $(7,10,11,16 / 1,16 / 2)$ for the owners and staff of the stadiums and the corresponding statements $(2,5,6,7 / 1,7 / 2)$ where the responses of owners and employees in approval rate (60.00: 86.67\%), while the responses of beneficiaries in the direction of disagreement (15.70: $33.88 \%$ ) with value of Chi ranging between $(50.37 *: 136.26 *$ ).

While the Center for International Private Enterprise (2018) concludes the findings of the Mohammed Khalid Al-Mahayni (2007) (31) study, governance requires transparency, credibility, and open-door policy, ultimately contributing to higher economic growth. (15: 46) 
The researcher believes that governance works to determine the policies related to the performance of the institution, and the classification of risks, management and determine the priorities for actions that should be based on which services are provided in these stadiums.

Table (11) Comparison of the results of iterations, percentages, Chi square, weighting ratio, average value and the prevailing direction of response to the first axis first dimension (Administrative components) for all groups

\begin{tabular}{|c|c|c|c|c|c|c|c|c|c|c|c|c|c|}
\hline \multicolumn{3}{|c|}{ State. number } & \multirow[b]{2}{*}{ Statement } & \multicolumn{3}{|c|}{ Owners and staff $=150$} & \multicolumn{3}{|c|}{ Officials $=27$} & \multicolumn{3}{|c|}{ Beneficiaries $=121$} & \multirow[b]{2}{*}{ Chi Sq. } \\
\hline 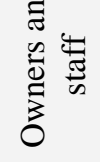 & $\begin{array}{l}\frac{\infty}{\pi} \\
: 0 \\
0 \\
0\end{array}$ & 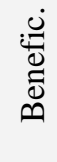 & & $\begin{array}{l}\text { Appro } \\
\text { v. rate }\end{array}$ & Direct. & $\begin{array}{c}\text { Weight. } \\
\text { ratio }\end{array}$ & $\begin{array}{c}\text { Approv } \\
\text {. rate }\end{array}$ & Direct. & $\begin{array}{c}\text { Weight. } \\
\text { ratio }\end{array}$ & $\begin{array}{c}\text { Approv } \\
\text {. rate }\end{array}$ & Direct. & $\begin{array}{c}\text { Weight. } \\
\text { ratio }\end{array}$ & \\
\hline 5 & 5 & 1 & $\begin{array}{l}\text { Private stadiums shall comply } \\
\text { with the building requirements } \\
\text { and health specifications. }\end{array}$ & 86.67 & Yes & 93.33 & 29.63 & No & 64.81 & 15.70 & No & $\mathbf{5 7 . 8 5}$ & $* 141.63$ \\
\hline
\end{tabular}

It is clear from Table (11) that there are no statistically significant differences between the responses of the three research samples on the statement (5) to the owners, employees and officials and the corresponding statement (1) to the beneficiaries where the responses came with disagreement with the officials and beneficiaries with the approval rate (29.63\%) (15.70\%) respectively and to the owners and employees came in the acceptable direction by $(86.67 \%)$ with value of Chi $141.63 *$.

In this regard, Manar Fikri Okasha asserts in Al-Mogeez journal (2018) that these stadiums violate the decisions of the Ministry of

Agriculture, and use electricity and lighting in ways that are contrary to the law, and they work to profit without a legal basis. (29: 3 )

According to the researcher, it is considered one of the main reasons for increasing the risks of private stadiums because they do not follow the building and health requirements, the researcher attributed this to the lack of specific frameworks that specify the course or steps and administrative elements that govern the work of the private stadiums (artificial turf). 
Table (12): Comparison of the results of iterations, percentages, Chi square, weighting ratio, average value and prevailing direction of the first axis second dimension (Legal components) for every two groups

\begin{tabular}{|c|c|c|c|c|c|c|c|c|c|c|c|c|c|c|c|c|c|}
\hline \multicolumn{3}{|c|}{ State. number } & \multirow[b]{3}{*}{ Statement } & \multicolumn{7}{|c|}{ Comparison of the groups (owners, staff and officials) } & \multicolumn{7}{|c|}{ Comparison of the groups (owners, staff and beneficiaries) } \\
\hline \multirow[b]{2}{*}{ 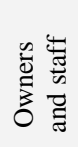 } & \multirow[b]{2}{*}{ 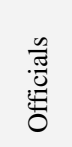 } & \multirow[b]{2}{*}{ 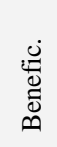 } & & \multicolumn{3}{|c|}{ Owners and staff $=150$} & \multicolumn{3}{|c|}{ Officials $=27$} & \multirow[b]{2}{*}{ Chi Sq. } & \multicolumn{3}{|c|}{ Owners and staff $=150$} & \multicolumn{3}{|c|}{ "Beneficiaries = 121 } & \multirow[b]{2}{*}{$\begin{array}{l}\text { Chi } \\
\text { Sq. }\end{array}$} \\
\hline & & & & $\begin{array}{c}\text { Approv. } \\
\text { rate }\end{array}$ & Direct. & $\begin{array}{l}\text { Weight. } \\
\text { ratio }\end{array}$ & $\begin{array}{l}\text { Approv. } \\
\text { rate }\end{array}$ & Direct. & $\begin{array}{c}\text { Weight. } \\
\text { ratio }\end{array}$ & & $\begin{array}{l}\text { Approv. } \\
\text { rate }\end{array}$ & Direct. & $\begin{array}{l}\text { Weight. } \\
\text { ratio }\end{array}$ & $\begin{array}{l}\text { Approv. } \\
\text { rate }\end{array}$ & Direct. & $\begin{array}{l}\text { Weight. } \\
\text { ratio }\end{array}$ & \\
\hline 17 & 11 & & $\begin{array}{l}\text { Specific safety and protection requirements of civil } \\
\text { defense will be complied with when issuing licenses. }\end{array}$ & 88.00 & Yes & 94.00 & 33.33 & No & 66.67 & $* 42.20$ & & & & & & & \\
\hline 18 & 12 & & $\begin{array}{l}\text { There are appropriate legal frameworks for the } \\
\text { establishment of private stadiums by the Ministry of } \\
\text { Youth. }\end{array}$ & 0.00 & No & 50.00 & 0.00 & No & 50.00 & 0.00 & & & & & & & \\
\hline 19 & 13 & & $\begin{array}{l}\text { Legal procedures are provided by agricultural } \\
\text { associations for the establishment of private stadiums. }\end{array}$ & 0.00 & No & 50.00 & 0.00 & No & 50.00 & 0.00 & & & & & & & \\
\hline 20 & 14 & & $\begin{array}{l}\text { Public investment laws are used to draft laws for } \\
\text { stadiums. }\end{array}$ & 0.00 & No & 50.00 & 25.93 & No & 62.96 & $* 40.49$ & & & & & & & \\
\hline 21 & 15 & & $\begin{array}{l}\text { Legal formulas concluded between the project owner } \\
\text { and the Ministry of Youth and Sports. }\end{array}$ & 0.00 & No & 50.00 & 0.00 & No & 50.00 & 0.00 & & & & & & & \\
\hline 22 & 16 & & $\begin{array}{l}\text { There are sanctions for the owners of the private } \\
\text { stadiums. }\end{array}$ & 73.33 & Yes & 86.67 & 25.93 & No & 62.96 & $* 22.95$ & & & & & & & \\
\hline 23 & 17 & 8 & Facing the risk of closing the stadium by the officials. & 0.00 & No & 50.00 & 33.33 & No & 66.67 & *52.68 & 0.00 & No & 50.00 & 32.23 & No & 66.12 & $\begin{array}{r}56.4 \\
* 7\end{array}$ \\
\hline 24 & 18 & & $\begin{array}{l}\text { There is a period of time given by the licensing } \\
\text { authorities. }\end{array}$ & 0.00 & No & 50.00 & 0.00 & No & 50.00 & 0.00 & & & & & & & \\
\hline 25 & 19 & & $\begin{array}{l}\text { A tax card can be issued for private stadiums (artificial } \\
\text { turf). }\end{array}$ & 80.00 & Yes & 90.00 & 70.37 & Yes & 85.19 & 1.26 & & & & & & & \\
\hline $26 / 1$ & $20 / 1$ & & Water. & 73.33 & Yes & 86.67 & 25.93 & No & 62.96 & $* 22.95$ & & & & & & & \\
\hline $26 / 2$ & $20 / 2$ & & Electrcity. & 66.67 & Yes & 83.33 & 18.52 & No & 59.26 & *21.98 & & & & & & & \\
\hline $26 / 3$ & $20 / 3$ & & Taxes. & 86.67 & Yes & 93.33 & 18.52 & No & 59.26 & *58.72 & & & & & & & \\
\hline 27 & & 9 & $\begin{array}{l}\text { There are internal regulations for the management of } \\
\text { the work of private stadiums (artificial turf). }\end{array}$ & & & & & & & & 90.00 & Yes & 95.00 & 46.28 & No & 73.14 & $\begin{array}{r}61.5 \\
* 3 \\
\end{array}$ \\
\hline
\end{tabular}

Value of Chi square $(1,0.05)=3.841$ Weighted average: No $(1: 1.5)$, Yes $(1.6: 2)$

All statements of the axis and its dimension except those common to the three groups will be presented and discussed in the following table.

It is clear from Table (12) that there are statistically significant differences between the responses of the owners and stadium staff and the group of officials in the concerned authorities about the statements $(18,19,21,24)$ of the owners and staff of the stadiums with statements 
corresponiding it $(12,13,15,18)$ for the officials that the responses of the two groups came in an unacceptable direction where they disagreed $(0.00 \%)$ for the two statements and the value of Chi $(0.00)$.

Manar Fikri Okasha (2018) confirms that a large percentage of citizens bulldozed the soil and set up buildings on it, but after the state removed it, they turned it into green stadiums with the slogan of serving the youth but instead profiting illegally. (29: 2)

The researcher agrees with the results of these statements and this is due to the fact that so far no laws have been developed or approved to regulate the work of these stadiums.

It is also clear that there are statistically significant differences between the responses of the owners and staff of the stadiums and the group of officials in the concerned authorities on the statement (25) for the owners and staff of the stadiums and the corresponding statement (19) to the officials in the concerned authorities where the responses of the two groups came with approve (80\%) (70.73\%) respectively and the value of Chi (1.26).

According to Muhammad Saad Farid (2015), the tax card is one of the most important documents issued by the Tax Authority, giving the owner the right to practice the activity inside the country, and is the first legal step to establish any project. (33:2)

The researcher believes that the positive views of the owners and employees of private stadiums and their agreement to issue a tax card in their favor so that they fall under the law to protect them from any problem that hinders work and may threaten to close the project as a whole.

The results also showed that there are statistically insignificant differences between the responses of the owners, employees group and the officials group regarding the statements $(17,22,26 / 1,26 / 2,26 / 3)$ for the owners and staff of the stadiums and the corresponding statements $(11$, $16,20 / 1,20 / 2,20 / 3$ ) where the responses of owners and employees in the direction of the approval rate (66.67: 88.00\%), while the responses of officials in the direction of disagreement by (18.52: 33.33\%) with value of Chi ranging between (21.98: 58.72).

Abdul Rahim Mohammed Abu Shama (2019) in Al-Wafd newspaper stresses the need to collect the right of the country, and to remove construction and electric power violations. (2:2)

The researcher agrees with the opinion of the officials because they are more familiar with monitoring the actual reality of these stadiums and disagree with the views of the owners of the stadiums because they want to show their facility updated contrary to the actual reality observed by the researcher during her study and visit to these stadiums during the application period.

While the responses were statistically insignificant between the groups of owners, employees and beneficiaries in the statement (27) and corresponding to (9) for the beneficiaries where the responses of owners and employees in the direction of approval by (90\%) while the opinions of the beneficiaries in the direction of disagreement by $(46.28 \%)$ and the value of Chi $(61.53 *)$.

The results of the study by Adel Abdul Rahman Ahmed (2003) (4) that the scientific organizations and legislative authorities to issue a set of regulations and laws and follow the principles of corporate governance to prevent or reduce future crises at least. 
The researcher agrees with the views of the beneficiaries as they are the ones who are to implement the services and are better able to monitor the deficiencies.

Table (13): Comparison of the results of iterations, percentages, Chi square, weighting ratio, average value and the prevailing direction of the first axis second dimension (Legal components) for all groups

\begin{tabular}{|c|c|c|c|c|c|c|c|c|c|c|c|c|c|}
\hline \multicolumn{3}{|c|}{ State. number } & \multirow[b]{2}{*}{ Statement } & \multicolumn{3}{|c|}{ Owners and staff $=150$} & \multicolumn{3}{|c|}{ Officials = 27} & \multicolumn{3}{|c|}{ Beneficiaries = 121} & \multirow[b]{2}{*}{ Chi Sq. } \\
\hline 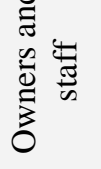 & $\begin{array}{l}\frac{\infty}{J} \\
: 0 \\
0 \\
0\end{array}$ & 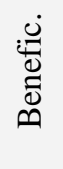 & & $\begin{array}{l}\text { Approv } \\
\text {. rate }\end{array}$ & $\begin{array}{c}\text { Direc } \\
\text { t. }\end{array}$ & $\begin{array}{c}\text { Weight. } \\
\text { ratio }\end{array}$ & $\begin{array}{c}\text { Appr } \\
\text { ov. } \\
\text { rate }\end{array}$ & $\begin{array}{c}\text { Direc } \\
\text { t. }\end{array}$ & $\begin{array}{c}\text { Weight. } \\
\text { ratio }\end{array}$ & $\begin{array}{c}\text { Appr } \\
\text { ov. } \\
\text { rate }\end{array}$ & Direct. & $\begin{array}{c}\text { Weight. } \\
\text { ratio }\end{array}$ & \\
\hline 23 & 17 & 8 & $\begin{array}{l}\text { Facing the risk of closing } \\
\text { stadium by the officials. }\end{array}$ & 0.00 & No & 50.00 & 33.33 & No & 66.67 & 32.23 & No & 66.12 & *58.01 \\
\hline
\end{tabular}

Value of Chi square $(2,0.05)=5.991$ Weighted average: No $(1: 1.5)$, Yes (1.6: 2$)$

It is clear from table (13) that there are statistically insignificant differences between the responses of the three research groups on the statement (23) to the owners and employees which corresponds to (17) for the officials and (8) for the beneficiaries, where the responses came in unacceptable direction ranging between $(0.00: 33.33 \%)$, with a value of Chi $(58.01 *)$.

In this regard, the Committee of Youth and Sports in the Parliament (2018) pointed to the aggravation of the crisis as there are more than (2178) unallocated stadiums in the Republic and must be separated and issued legislation. (50)

The researcher agrees with this conclusion, as through newspapers and close viewing, the closure and demolition of these stadiums is repeated by the Ministry of Interior and the Ministry of Agriculture. 
Table (14) Comparison of results of iterations, Chi square, weighted ratio, average value and prevailing direction for the First Axis Third Dimension (Financial, human and informatics components) for every two groups

\begin{tabular}{|c|c|c|c|c|c|c|c|c|c|c|c|c|c|c|c|c|c|}
\hline \multicolumn{3}{|c|}{ State. number } & \multirow[b]{3}{*}{ Statement } & \multicolumn{7}{|c|}{ Comparison of the groups (owners, staff and officials) } & \multicolumn{7}{|c|}{ Comparison of the groups (owners, staff and beneficiaries) } \\
\hline \multirow[b]{2}{*}{ 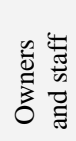 } & \multirow[b]{2}{*}{$\underset{0}{\frac{n}{6}}$} & \multirow[b]{2}{*}{ 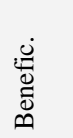 } & & \multicolumn{3}{|c|}{ Owners and staff $=150$} & \multicolumn{3}{|c|}{ Officials $=27$} & \multirow[b]{2}{*}{$\begin{array}{l}\text { Chi } \\
\text { Sq. }\end{array}$} & \multicolumn{3}{|c|}{ Owners and staff $=150$} & \multicolumn{3}{|c|}{ Beneficiaries $=121$} & \multirow[b]{2}{*}{$\begin{array}{l}\text { Chi } \\
\text { Sq. }\end{array}$} \\
\hline & & & & $\begin{array}{c}\text { Approv. } \\
\text { rate }\end{array}$ & Direct. & $\begin{array}{l}\text { Weight. } \\
\text { ratio }\end{array}$ & $\begin{array}{l}\text { Approv. } \\
\text { rate }\end{array}$ & Direct & $\begin{array}{l}\text { Weight. } \\
\text { ratio }\end{array}$ & & $\begin{array}{l}\text { Approv. } \\
\text { rate }\end{array}$ & Direct & $\begin{array}{l}\text { Weight. } \\
\text { ratio }\end{array}$ & $\begin{array}{l}\text { Approv. } \\
\text { rate }\end{array}$ & Direct. & $\begin{array}{l}\text { Weight. } \\
\text { ratio }\end{array}$ & \\
\hline 28 & 21 & & $\begin{array}{l}\text { Financial budgets are allocated by the Ministry of } \\
\text { Youth and Sports to implement and support the } \\
\text { project. }\end{array}$ & 0.00 & No & 50.00 & 0.00 & No & 50.00 & 0.00 & & & & & & & \\
\hline 29 & & 10 & $\begin{array}{l}\text { The administration is working to make the best use of all the } \\
\text { resources available in the private stadiums (artificial turf). }\end{array}$ & & & & & & & & 92.67 & Yes & 96.33 & 17.36 & No & 58.68 & *157.08 \\
\hline $30 / 1$ & $22 / 1$ & $11 / 1$ & For medical care. & 56.67 & Yes & 78.33 & 25.93 & No & 62.96 & *8.66 & 56.67 & Yes & 78.33 & 18.18 & No & 59.09 & ${ }^{*} 41.51$ \\
\hline $30 / 2$ & $22 / 2$ & $11 / 2$ & For various sports activities. & 92.67 & Yes & 96.33 & 81.48 & Yes & 90.74 & 3.48 & 92.67 & Yes & 96.33 & 17.36 & No & 58.68 & ${ }^{*} 157.08$ \\
\hline 31 & 23 & 12 & $\begin{array}{l}\text { There is a committee to follow up all the activities and } \\
\text { services provided in the private stadiums. }\end{array}$ & 64.00 & Yes & 82.00 & 0.00 & No & 50.00 & $* 37.76$ & 64.00 & Yes & 82.00 & 21.49 & No & 60.74 & ${ }^{* 48.90}$ \\
\hline 32 & 24 & 13 & $\begin{array}{l}\text { There is a technical committee to ensure the validity of } \\
\text { the place used to set up the stadium. }\end{array}$ & 63.33 & Yes & 81.67 & 0.00 & No & 50.00 & ${ }^{* 36.91}$ & 63.33 & Yes & 81.67 & 21.49 & No & 60.74 & ${ }^{* 47.45}$ \\
\hline 33 & 25 & & $\begin{array}{l}\text { There is a willingness to follow the procedures } \\
\text { necessary to issue licenses. }\end{array}$ & 100 & Yes & 100 & 0.00 & No & 50.00 & ${ }^{*} \mathbf{1 7 7 . 0 0}$ & & & & & & & \\
\hline 34 & & 14 & $\begin{array}{l}\text { Committed to appoint a technician to maintain the } \\
\text { artificial turf and stadiums within the team } \\
\text { responsible for the stadium. }\end{array}$ & & & & & & & & 20.00 & No & 60.00 & 38.02 & No & 69.01 & ${ }^{* 10.77}$ \\
\hline $35 / 1$ & & $15 / 1$ & Administrators working in the private stadium. & & & & & & & & 92.67 & Yes & 96.33 & 17.36 & No & 58.68 & ${ }^{*}$ 157.08 \\
\hline $35 / 2$ & & $15 / 2$ & Trainers. & & & & & & & & 90.00 & Yes & 95.00 & 82.64 & Yes & 91.32 & 3.15 \\
\hline 36 & & 16 & $\begin{array}{l}\text { There is a website for the private stadium (artificial } \\
\text { turf) to market its various activities. }\end{array}$ & & & & & & & & 33.33 & No & 66.67 & 33.88 & No & 66.94 & 0.01 \\
\hline $37 / 1$ & & $17 / 1$ & Competitors in the field. & & & & & & & & 20.00 & No & 60.00 & 38.02 & No & 69.01 & ${ }^{* 10.77}$ \\
\hline $37 / 2$ & & $17 / 2$ & Surrounding environment and residents. & & & & & & & & 20.00 & No & 60.00 & 38.02 & No & 69.01 & $* 10.77$ \\
\hline $37 / 3$ & & $17 / 3$ & Beneficiaries and players of the activities that are offered. & & & & & & & & 98.00 & Yes & 99.00 & 98.35 & Yes & 99.17 & 0.04 \\
\hline $38 / 1$ & & $18 / 1$ & The category served by the private stadium. & & & & & & & & 73.33 & Yes & 86.67 & 9.09 & No & 54.55 & ${ }^{* 111.84}$ \\
\hline $38 / 2$ & & $18 / 2$ & Satisfaction with services. & & & & & & & & 73.33 & Yes & 86.67 & 9.09 & No & 54.55 & ${ }^{* 111.84}$ \\
\hline $38 / 3$ & & $18 / 3$ & Their needs and the requirements of the beneficiaries. & & & & & & & & 90.00 & Yes & 95.00 & 82.64 & Yes & 91.32 & 3.15 \\
\hline $39 / 1$ & & $19 / 1$ & School students. & & & & & & & & 92.67 & Yes & 96.33 & 17.36 & No & 58.68 & ${ }^{* 157.08}$ \\
\hline $39 / 2$ & & $19 / 2$ & Institute students. & & & & & & & & 98.00 & Yes & 99.00 & 98.35 & Yes & 99.17 & 0.04 \\
\hline $39 / 3$ & & $19 / 3$ & University Students. & & & & & & & & 72.67 & Yes & 86.33 & 76.03 & Yes & 88.02 & 0.40 \\
\hline $39 / 4$ & & $19 / 4$ & Employees. & & & & & & & & 72.67 & Yes & 86.33 & 76.03 & Yes & 88.02 & 0.40 \\
\hline $39 / 5$ & & $19 / 5$ & Self Employed. & & & & & & & & 92.67 & Yes & 96.33 & 17.36 & No & 58.68 & ${ }^{* 157.08}$ \\
\hline
\end{tabular}


Table (14) Comparison of results of iterations, Chi square, weighted ratio, average value and prevailing direction for the First Axis Third Dimension (Financial,

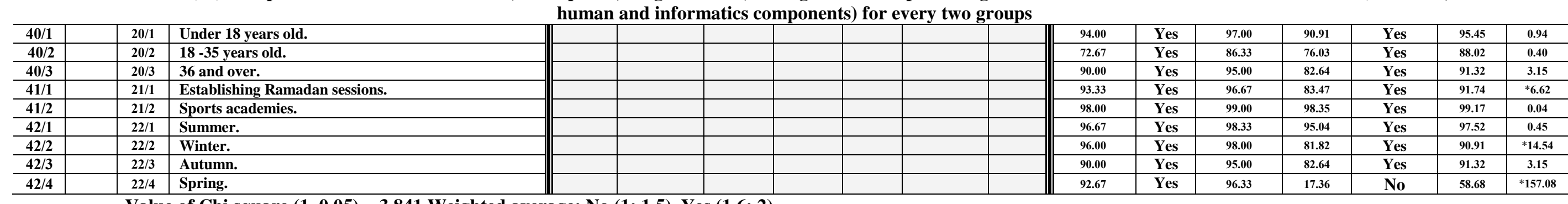

Value of Chi square $(1,0.05)=3.841$ Weighted average: No $(1: 1.5)$, Yes (1.6: 2$)$

All statements of the axis and its dimension except those common to the three groups will be presented and discussed in the following table.

It is clear from table (14) that there are statistically significant differences between the responses of owners and staff of the stadiums and officials of the concerned authorities on the statement (28) to the owners and staff of the stadiums and corresponds to the statement (21) to the officials of the concerned authorities, although the responses of the two groups came in an unacceptable direction $(0.00 \%)$ with the value of Chi (0.00).

The study of Waddah Mohammed Jassem (2018) (45) recommends the need to set an appropriate budget for all plans put in place for institutions to address risks of various types.

The researcher believes that these projects should be supported by the Ministry of Youth and Sports and the country institutions because of their effective role in promoting sport.

It is also clear that there are statistically insignificant differences between the responses of owners, employees and officials on the statement (33) for the group of owners and staff of the stadiums and corresponds to (25) where the responses of owners and employees came in acceptable direction by $(100 \%)$ while the responses of officials in disagreement by $(0.00 \%)$ with the value of Chi $(177.00 *)$, however, that there is a willingness to follow the necessary procedures to issue licenses for private stadiums.

In this regard, Nevin Jamea Hassan (2019), Chief Executive Officer of the Entrepreneurship Authority (2019), stressed the need to pay attention to facilitating tax procedures and licensing facilities, as state institutions should take positive steps in the small business sector. $(37: 2)(50)$

The researcher agrees with this finding and with the owners and staff because everyone is looking for protection and work without threats to achieve their goals or stop their services. 
It is also clear from the table that there are statistically significant differences between the responses of owners and employees and beneficiaries groups on statement (36) and corresponds to (16), although the responses of the two groups came in an unacceptable direction by $(33.33 \%)(33.88 \%)$ respectively with the value of Chi (0.01).

In this regard, Mohammed Mustafa Suleiman (2006) points out that technological progress plays an important and prominent role in the process of modernization and development in various institutions. Governance is one of the most prominent features of the technological age (32: 39).

The researcher agrees with this result, searching on the Internet for these stadiums and found that there is very little that has a website. The results of the table also showed that there are statistically significant differences between the responses of the owners , employees and beneficiaries on the statements $(35 / 2,37 / 3,38 / 3,39 / 2,39 / 3,39 / 4,40 / 1,40 / 2,40 / 3,41 / 2,42 / 1,42 / 3)$ corresponding to $(15 / 2$, 17/3, 18/3, 19/2, $19 / 3,19 / 4,20 / 1,20 / 2,20 / 3,21 / 2,22 / 1,22 / 3)$, The responses for both groups came in an acceptable direction ranging from (72.67: $98.00 \%$ ) (76.03: 98.35\%) respectively and the value of Chi (0.04: 3.15).

The World Health Organization (2018) emphasizes that to reduce the risk of disease, different age groups should be physically active.This applies to all adults, male and female, and work to fill their leisure time to improve cardiovascular fitness and muscle fitness. (46: 1)

The researcher attributes these results and the increase in the participants rate for those under 18 years because they have free time to practice sports activity. The most attractive season for sports is summer due to study holidays.

The responses were statistically insignificant between the groups of owners, employees and beneficiaries on the statements (34, 37/1, 37/2) corresponding $(14,17 / 1,17 / 2)$ to the beneficiaries where the responses of the two groups in an unacceptable direction (20.00\%) $(38.02 \%)$ respectively for all statements, and the value of Chi $(10.77 *)$.

The study of Noura Mohammed Al-Shamri (2011) (38) recommends the need to identify technical elements in institutions to ensure good performance of their work financially and technically.

The researcher agrees with the results of these statements. These stadiums by reference were found that the responsibility for the maintenance of the grass is under the responsibility of the contracted parties when they are established, as the researcher believes that databases are one of the basic steps that contribute to success and a bridge to identify the strengths and weaknesses in the level of services provided.

While the responses were statistically insignificant between the groups of owners, employees and beneficiaries on the statements $(41 / 1,42 / 2)$ corresponding $(21 / 1,22 / 2)$ for the beneficiaries where the responses of the two groups in the direction of approval (93.33: 96.00\%) (81.82:83.47\%) respectively and the value of Chi (6.62: 14.54).

Ahmed Farid Hassan (2017) asserts that exercise in Ramadan is considered to be of great importance and benefits to the body as it provides it with vitality and works to maintain its agility and gain health and proper structure. $(7: 13)$ 
The researcher agrees with the statements as Ramadan is one of the most practicing months of sport due to the desire of many youth to spend the time of fasting.

The responses were statistically insignificant between the groups of owners, employees and beneficiaries on the statements $(29,35 / 1,38 / 1,38 / 2$, $39 / 1,39 / 5,42 / 4)$ and corresponding $(10,15 / 1,18 / 1,18 / 2,19 / 1,19 / 5,22 / 4)$ to the beneficiaries, where the responses of owners and employees were in acceptable direction ranging between (73.33: 92.67\%) while the group of beneficiaries went unacceptably by (9.09: 17.36\%) and the value of Chi (111.84: $157.08 *)$.

The study of Osama Said Abdel Sadek and Osama Hanafi Mahmoud (2009) (39) recommends the need to satisfy the technical and administrative cadres, which is an indispensable indicator for a company aspiring to continue to compete at the local or regional level.

The researcher agrees with the beneficiaries on those statements as according to personal interviews conducted by the researcher with some beneficiaries found their dissatisfaction with many services, and the researcher also attributed the lack of optimal use of the resources available in private stadiums because of the lack of a plan based on scientific basis.

Table (15) Comparison of results of frequencies, Chi square, weighting ratio, average value and prevailing direction of the First axis Third dimension (Financial, human and informatics components) for all groups

\begin{tabular}{|c|c|c|c|c|c|c|c|c|c|c|c|c|c|}
\hline \multicolumn{3}{|c|}{ State. number } & \multirow[b]{2}{*}{ Statement } & \multicolumn{3}{|c|}{ Owners and staff $=150$} & \multicolumn{3}{|c|}{ Officials $=27$} & \multicolumn{3}{|c|}{ Beneficiaries = 121} & \multirow[b]{2}{*}{ Chi Sq. } \\
\hline 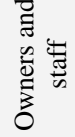 & 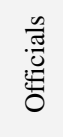 & $\begin{array}{l}\dot{0} \\
\stackrel{0}{D} \\
\stackrel{0}{0}\end{array}$ & & $\begin{array}{c}\text { Approv. } \\
\text { rate }\end{array}$ & Direct. & $\begin{array}{l}\text { Weight. } \\
\text { ratio }\end{array}$ & $\begin{array}{c}\text { Approv. } \\
\text { rate }\end{array}$ & Direct. & $\begin{array}{l}\text { Weight. } \\
\text { ratio }\end{array}$ & $\underset{\text { rate }}{\text { Approv. }}$ & Direct. & Weight. ratio & \\
\hline $30 / 1$ & $22 / 1$ & $11 / 1$ & For medical care. & 56.67 & Yes & 78.33 & 25.93 & No & 62.96 & 18.18 & No & 59.09 & $* 43.91$ \\
\hline $30 / 2$ & $22 / 2$ & $11 / 2$ & For various sports activities. & 92.67 & Yes & 96.33 & 81.48 & Yes & 90.74 & 17.36 & No & 58.68 & *164.98 \\
\hline 31 & 23 & 12 & $\begin{array}{l}\text { There is a committee to follow up all the } \\
\text { activities and services provided in the } \\
\text { private stadiums. }\end{array}$ & 64.00 & Yes & 82.00 & 0.00 & No & $\mathbf{5 0 . 0 0}$ & 21.49 & No & 60.74 & $* 70.64$ \\
\hline 32 & 24 & 13 & $\begin{array}{l}\text { There is a technical committee to ensure } \\
\text { the validity of the place used to set up the } \\
\text { stadium. }\end{array}$ & 63.33 & Yes & 81.67 & 0.00 & No & $\mathbf{5 0 . 0 0}$ & 21.49 & No & 60.74 & *68.92 \\
\hline
\end{tabular}

Value of Chi square $(2,0.05)=5.991$ Weighted average: No $(1: 1.5)$, Yes $(1.6: 2)$

It is clear from Table (15) that there are statistically insignificant differences between the responses of the three groups on the statements $(30 / 1$, $31,32)$ to the owners and employees and corresponds $(22 / 1,23,24)$ to the officials and corresponds $(11 / 1,12,13)$ to the beneficiaries where the responses of the owners and employees of the stadiums came in an acceptable direction ranging between (56.67: 64.00\%), while the responses of officials and beneficiaries in an unacceptable direction ranged between (0.00: 25.93\%) (18.18: 21.49\%), the value of Chi (43.91: 70.64). 
The results of Archambeault study, Deborah S., (2002), (10) confirm that governance in a nutshell is the way of managing institutions in a transparent manner, subject to control and followed to achieve the highest degree of work performance.

The researcher agrees with the officials and beneficiaries because there is already no medical equipment or first aid in these stadiums, and there are no committees in these stadiums, as most of them only have the owner of the stadium and staff.

Table (16): Comparison of the results of iterations, percentages, Chi square, weighting ratio, average value and the prevailing direction of the first axis fourth dimension (Technical components) for every two groups

\begin{tabular}{|c|c|c|c|c|c|c|c|c|c|c|c|c|c|c|c|c|c|}
\hline \multicolumn{3}{|c|}{ State. number } & \multirow{3}{*}{ Statement } & \multicolumn{7}{|c|}{ Comparison of the groups (owners, staff and officials) } & \multicolumn{7}{|c|}{ Comparison of the groups (owners, staff and beneficiaries) } \\
\hline \multirow{2}{*}{ 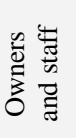 } & \multirow{2}{*}{ 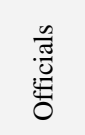 } & \multirow{2}{*}{ 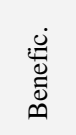 } & & \multicolumn{3}{|c|}{ Owners and staff $=\mathbf{1 5 0}$} & \multicolumn{3}{|c|}{ Officials $=27$} & \multirow[b]{2}{*}{$\begin{array}{l}\text { Chi } \\
\text { Sq. }\end{array}$} & \multicolumn{3}{|c|}{ Owners and staff $=150$} & \multicolumn{3}{|c|}{ Beneficiaries $=121$} & \multirow[b]{2}{*}{$\begin{array}{l}\text { Chi } \\
\text { Sq. }\end{array}$} \\
\hline & & & & $\begin{array}{l}\text { Approv. } \\
\text { rate }\end{array}$ & Direct. & $\begin{array}{l}\text { Weight. } \\
\text { ratio }\end{array}$ & $\begin{array}{l}\text { Approv. } \\
\text { rate }\end{array}$ & Direct. & $\begin{array}{l}\text { Weight. } \\
\text { ratio }\end{array}$ & & $\begin{array}{l}\text { Approv. } \\
\text { rate }\end{array}$ & Direct. & $\begin{array}{l}\text { Weight. } \\
\text { ratio }\end{array}$ & $\begin{array}{l}\text { Approv. } \\
\text { rate }\end{array}$ & Direct. & $\begin{array}{l}\text { Weight. } \\
\text { ratio }\end{array}$ & \\
\hline $43 / 1$ & $26 / 1$ & $23 / 1$ & $\begin{array}{l}\text { Isolate stadiums with a net height of } 6 \mathrm{~m} \text { to take the } \\
\text { neighborhood into account. }\end{array}$ & 100 & Yes & 100 & 74.07 & Yes & 87.04 & $* 40.49$ & 100 & Yes & 100 & 70.25 & Yes & 85.12 & *51.46 \\
\hline $43 / 2$ & $26 / 2$ & $23 / 2$ & $\begin{array}{l}\text { The width of the street overlooking the stadium shall not be } \\
\text { less than } 20 \mathrm{~m} \text {. }\end{array}$ & 40.00 & No & 70.00 & 77.78 & Yes & 88.89 & *13.16 & 40.00 & No & 70.00 & 74.38 & Yes & 87.19 & *32.03 \\
\hline $43 / 3$ & $26 / 3$ & $23 / 3$ & The outer fence is at least $3 \mathrm{~m}$ away from the stadium. & 33.33 & No & 66.67 & $\mathbf{7 4 . 0 7}$ & Yes & 87.04 & *15.89 & 33.33 & No & 66.67 & 32.23 & No & 66.12 & 0.04 \\
\hline $43 / 4$ & $26 / 4$ & $23 / 4$ & $\begin{array}{l}\text { The lighting poles should be at least } 3 \mathrm{~m} \text { away from the } \\
\text { stadium. }\end{array}$ & 30.00 & No & 65.00 & 74.07 & Yes & 87.04 & $* 19.13$ & 30.00 & No & 65.00 & 42.15 & No & 71.07 & $* 4.32$ \\
\hline $43 / 5$ & 26/5 & $23 / 5$ & $\begin{array}{l}\text { A guard shall be placed at least } 3 \mathrm{~m} \text { in length around the } \\
\text { lighting poles surrounding the stadium. }\end{array}$ & 87.33 & Yes & 93.67 & 85.19 & Yes & 92.59 & 0.09 & 87.33 & Yes & 93.67 & 12.40 & No & 56.20 & ${ }^{* 151.35}$ \\
\hline $43 / 6$ & $26 / 6$ & $23 / 6$ & $\begin{array}{l}\text { The use of internationally certified artificial turf in the } \\
\text { stadiums. }\end{array}$ & 100 & Yes & 100 & 81.48 & Yes & 90.74 & $* 28.59$ & 100 & Yes & 100 & 19.83 & No & 59.92 & ${ }^{* 187.28}$ \\
\hline $\begin{array}{c}17 / 1 \\
43 \\
\end{array}$ & $26 / 7 / 1$ & $\begin{array}{c}17 / 1 \\
23 \\
\end{array}$ & Dressing rooms. & 80.67 & Yes & 90.33 & 81.48 & Yes & 90.74 & 0.01 & 80.67 & Yes & 90.33 & 18.18 & No & 59.09 & *104.92 \\
\hline $\begin{array}{c}17 / 2 \\
43 \\
\end{array}$ & $26 / 7 / 2$ & $\begin{array}{c}17 / 2 \\
23 \\
\end{array}$ & Bathrooms . & 100 & Yes & 100 & 100 & Yes & 100 & 0.00 & 100 & Yes & 100 & 33.88 & No & 66.94 & ${ }^{* 140.71}$ \\
\hline $\begin{array}{c}17 / 3 \\
43 \\
\end{array}$ & $26 / 7 / 3$ & $\begin{array}{c}17 / 3 \\
23\end{array}$ & Medical unit. & 40.00 & No & 70.00 & 100 & Yes & 100 & *32.96 & 40.00 & No & 70.00 & 9.92 & No & 54.96 & *31.07 \\
\hline $43 / 8$ & $26 / 8$ & $23 / 8$ & $\begin{array}{l}\text { Provide fire alarm and fire extinguishers to benefit from } \\
\text { them when needed. }\end{array}$ & 94.67 & Yes & 97.33 & 100 & Yes & 100 & 1.51 & 94.67 & Yes & 97.33 & 0.83 & No & 50.41 & ${ }^{* 236.63}$ \\
\hline $43 / 9$ & $26 / 9$ & $23 / 9$ & $\begin{array}{l}\text { It is forbidden to use the entrances and exits on the main } \\
\text { streets. }\end{array}$ & 42.00 & No & 71.00 & 81.48 & Yes & 90.74 & *14.29 & 42.00 & No & 71.00 & 10.74 & No & 55.37 & ${ }^{*} 32.42$ \\
\hline $\begin{array}{r}/ 10 \\
43 \\
\end{array}$ & & 23/10 & $\begin{array}{l}\text { The services provided by private stadiums meet all the needs } \\
\text { of the beneficiaries. }\end{array}$ & & & & & & & & 40.00 & No & 70.00 & 38.02 & No & 69.01 & 0.11 \\
\hline $44 / 1$ & 27/1 & $24 / 1$ & Tools. & 86.67 & Yes & 93.33 & 92.59 & Yes & 96.30 & 0.74 & 86.67 & Yes & 93.33 & 26.45 & No & 63.22 & ${ }^{*} 101.02$ \\
\hline $44 / 2$ & $27 / 2$ & $24 / 2$ & Equipment. & 81.33 & Yes & 90.67 & 85.19 & Yes & 92.59 & 0.23 & 81.33 & Yes & 90.67 & 29.75 & No & 64.88 & *73.30 \\
\hline $44 / 3$ & $27 / 3$ & $24 / 3$ & Playgrounds. & 86.00 & Yes & 93.00 & 74.07 & Yes & 87.04 & 2.44 & 86.00 & Yes & 93.00 & 24.79 & No & 62.40 & ${ }^{* 103.47}$ \\
\hline
\end{tabular}




\begin{tabular}{|c|c|c|c|c|c|c|c|c|c|c|c|c|c|c|c|c|c|}
\hline $45 / 1$ & & $25 / 1$ & Staff. & & & & & & & & 87.33 & Yes & $\mathbf{9 3 . 6 7}$ & 12.40 & No & 56.20 & *151.35 \\
\hline $45 / 2$ & & $25 / 2$ & Beneficiaries of sports activities. & & & & & & & & 94.67 & Yes & 97.33 & 0.83 & No & 50.41 & *236.63 \\
\hline $46 / 1$ & $28 / 1$ & & Ministry of Youth and Sports. & 100 & Yes & 100 & 92.59 & Yes & 96.30 & *11.24 & & & & & & & \\
\hline $46 / 2$ & $28 / 2$ & & Youth and Sports Directorate. & 100 & Yes & 100 & 100 & Yes & 100 & 0.00 & & & & & & & \\
\hline $46 / 3$ & $28 / 3$ & & Ministry of Health. & 45.00 & No & 75.00 & 29.63 & No & 64.81 & 3.81 & & & & & & & \\
\hline $46 / 4$ & $28 / 4$ & & Ministry Of Agriculture. & 40.00 & No & 70.00 & 37.04 & No & 68.52 & 0.08 & & & & & & & \\
\hline $46 / 5$ & $28 / 5$ & & General Authority for Investment. & 40.00 & No & 70.00 & 29.63 & No & 64.81 & 1.04 & & & & & & & \\
\hline
\end{tabular}

Value of Chi square $(1,0.05)=3.841$ Weighted average: No $(1: 1.5)$, Yes (1.6: 2$)$.

All statements of the axis and its dimension except those common to the three groups will be presented and discussed in the following table.

It is clear from Table (16) that there are statistically significant differences between the responses of owners, employees and officials on the statementss $(46 / 3,46 / 4,46 / 5)$ and corresponding $(28 / 3,28 / 4,28 / 5)$, although the responses came with disagreemnet $(40: 45.00 .00 \%)(29.63$ : $37.04 \%)$ respectively with the value of Chi (0.08: 3.81), and the opinions were acceptable (100\%) to the Directorate of Youth and Sports where there was statistically insignificant differences with approval (100\%).

Sayed Hassan Mohamed (2019) asserts that the private stadiums are supposed to be under the supervision of the Directorate of Youth and Sports in various governorates. (42: 1)

The researcher agrees with this result because of the nature of the work of the Directorate of Youth and Sports and its competence and close association with the private stadiums of the youth centers.

It is also clear that there are statistically significant differences between the responses of owners, employees and beneficiaries on the statement (43/10) and corresponding (23/10), although the responses came in an unacceptable direction (40.00\%) (38.02\%) respectively with the value of Chi $(0.11)$.

According to Manar Fikri Okasha (2018), the cost of establishing such stadiums costs more than (150,000 Egyptian pounds) if equipped with artificial turf, which is not the gain that covers the cost of providing other services. (29:2)

The researcher agrees with the results of the statement that the owners of the stadiums may not have the material or human resources that enable them to provide a variety of services. 
Table (17): Comparison of the results of iterations, percentages, Chi square, weighting ratio, average value and prevailing direction of responses on the first axis fourth dimension (Technical components) for all groups

\begin{tabular}{|c|c|c|c|c|c|c|c|c|c|c|c|c|c|}
\hline \multicolumn{3}{|c|}{ State. number } & \multirow[b]{2}{*}{ Statement } & \multicolumn{3}{|c|}{ Owners and staff $=150$} & \multicolumn{3}{|c|}{ Officials $=27$} & \multicolumn{3}{|c|}{ Beneficiaries $=121$} & \multirow[b]{2}{*}{ Chi Sq. } \\
\hline 岂 & $\underbrace{\frac{\pi}{0}}_{0}$ & 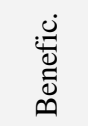 & & $\begin{array}{l}\text { Appro } \\
\text { v. rate }\end{array}$ & $\begin{array}{l}\text { Dire } \\
\text { ct. }\end{array}$ & $\begin{array}{c}\text { Weigh } \\
\text { t. } \\
\text { ratio }\end{array}$ & $\begin{array}{l}\text { Appro } \\
\text { v. rate }\end{array}$ & $\begin{array}{l}\text { Dire } \\
\text { ct. }\end{array}$ & $\begin{array}{l}\text { Weight } \\
\text {. ratio }\end{array}$ & $\begin{array}{l}\text { Appro } \\
\text { v. rate }\end{array}$ & $\begin{array}{l}\text { Dire } \\
\text { ct. }\end{array}$ & $\begin{array}{l}\text { Weight. } \\
\text { ratio }\end{array}$ & \\
\hline $43 / 1$ & $26 / 1$ & $23 / 1$ & $\begin{array}{l}\text { Isolate stadiums with a net height of } 6 \mathrm{~m} \text { to take the } \\
\text { neighborhood into account. }\end{array}$ & 100 & Yes & 100 & 74.07 & Yes & 87.04 & 70.25 & Yes & 85.12 & *51.19 \\
\hline $43 / 2$ & $26 / 2$ & $23 / 2$ & $\begin{array}{l}\text { The street width overlooking the stadium shall not be } \\
\text { less than } 20 \mathrm{~m} \text {. }\end{array}$ & 40.00 & No & 70.00 & 77.78 & Yes & 88.89 & 74.38 & Yes & 87.19 & $* 37.42$ \\
\hline $43 / 3$ & $26 / 3$ & $23 / 3$ & The outer fence is at least $3 \mathrm{~m}$ away from the stadium. & 33.33 & No & 66.67 & 74.07 & Yes & 87.04 & 32.23 & No & 66.12 & $* 18.03$ \\
\hline $43 / 4$ & $26 / 4$ & $23 / 4$ & $\begin{array}{l}\text { The lighting poles should be at least } 3 \mathrm{~m} \text { away from the } \\
\text { stadium. }\end{array}$ & 30.00 & No & 65.00 & 74.07 & Yes & 87.04 & 42.15 & No & 71.07 & $* 19.59$ \\
\hline $43 / 5$ & $26 / 5$ & $23 / 5$ & $\begin{array}{l}\text { A guard shall be placed at least } 3 \mathrm{~m} \text { in length around the } \\
\text { lighting poles surrounding the stadium. }\end{array}$ & 87.33 & Yes & 93.67 & 85.19 & Yes & 92.59 & 12.40 & No & 56.20 & $* 163.00$ \\
\hline $43 / 6$ & $26 / 6$ & $23 / 6$ & $\begin{array}{l}\text { Use internationally certified artificial turf in the } \\
\text { stadiums. }\end{array}$ & 100 & Yes & 100 & 81.48 & Yes & 90.74 & 19.83 & No & 59.92 & *194.44 \\
\hline $\begin{array}{c}17 / 1 \\
43\end{array}$ & $\begin{array}{c}17 / 1 \\
26\end{array}$ & $\begin{array}{c}17 / 1 \\
23\end{array}$ & Dressing rooms. & 80.67 & Yes & 90.33 & 81.48 & Yes & 90.74 & 18.18 & No & 59.09 & $* 114.01$ \\
\hline $\begin{array}{c}17 / 2 \\
43\end{array}$ & $\begin{array}{c}17 / 2 \\
26\end{array}$ & $\begin{array}{c}17 / 2 \\
23\end{array}$ & Bathrooms . & 100 & Yes & 100 & 100 & Yes & 100 & 33.88 & No & 66.94 & *159.97 \\
\hline $\begin{array}{c}17 / 3 \\
43\end{array}$ & $\begin{array}{c}17 / 3 \\
26\end{array}$ & $\begin{array}{c}17 / 3 \\
23\end{array}$ & Medical unit. & 40.00 & No & 70.00 & 100 & Yes & 100 & 9.92 & No & 54.96 & $* 87.00$ \\
\hline $43 / 8$ & $26 / 8$ & $23 / 8$ & $\begin{array}{l}\text { Provide fire alarm and fire extinguishers to use when } \\
\text { needed. }\end{array}$ & 94.67 & Yes & $\mathbf{9 7 . 3 3}$ & 100 & Yes & 100 & 0.83 & No & 50.41 & $* 263.05$ \\
\hline $43 / 9$ & $26 / 9$ & $23 / 9$ & $\begin{array}{l}\text { Prohibit using the entrances and exits on the main } \\
\text { streets. }\end{array}$ & 42.00 & No & 71.00 & 81.48 & Yes & 90.74 & 10.74 & No & $\mathbf{5 5 . 3 7}$ & $* 61.41$ \\
\hline $44 / 1$ & $27 / 1$ & $24 / 1$ & Tools. & 86.67 & Yes & 93.33 & 92.59 & Yes & 96.30 & 26.45 & No & 63.22 & $* 115.22$ \\
\hline $44 / 2$ & $27 / 2$ & $24 / 2$ & Equipment. & 81.33 & Yes & 90.67 & 85.19 & Yes & 92.59 & 29.75 & No & 64.88 & \begin{tabular}{|l|}
$* 82.16$ \\
\end{tabular} \\
\hline $44 / 3$ & $27 / 3$ & $24 / 3$ & Playgrounds. & 86.00 & Yes & 93.00 & 74.07 & Yes & 87.04 & 24.79 & No & 62.40 & *107.03 \\
\hline
\end{tabular}

Value of Chi square $(2,0.05)=5.991$ Weighted average: No $(1: 1.5)$, Yes (1.6: 2)

It is clear from Table (17) that there are statistically insignificant differences between the responses of the three research samples on the statements $(43 / 3,43 / 4,43 / 7 / 3,43 / 9)$ to the owners and employees and corresponding $(26 / 3,26 / 4,26 / 7 / 3,26 / 9)$ to the officials and corresponding 
$(23 / 3,23 / 4,23 / 7 / 3,23 / 9)$ to the beneficiaries where the responses of owners and staff of the stadiums and beneficiaries were in an unacceptable direction ranged between (30.00:42\%)(9.92:42.15\%), while the responses of the officials' group went in an acceptable direction ranging between (74.07: 100\%) with a value of Chi (18.03: 87.00)

Kefaya Abbadi (2018) also indicates that the private stadiums must have technical and legal specifications and should not be departed from them by all concerned parties. (27: 2)

The researcher agrees with the opinion of the owners and staff of the stadiums and beneficiaries as it is necessary for private stadiums to obtain licenses to comply with the technical and legal conditions, and attributed the opinion of officials to the mental image of these stadiums, where it only seeks the financial gain.

The results also showed that there were statistically insignificant differences between the responses on the statements $(43 / 5,43 / 6,43 / 7 / 1,43 / 7 / 2$, 43/8, 44/1, 44/2, 44/3) for owners and employees and corresponding (26/5, 26/6, 26/7/1, 26/7/2, 26/8, 27/1, 27/2, 27/3) for officials and corresponding $(23 / 5,23 / 6,23 / 7 / 1,23 / 7 / 2,23 / 8,24 / 1,24 / 2,24 / 3)$ to the beneficiaries, where the responses of owners, employees, and officials came in an acceptable direction ranging between (80.67: 100\%) (74.07: 100\%), while the responses of the beneficiary group went in an unacceptable direction by $(0.83: 33.88 \%)$, with a value of Chi $\left(82.16: 263.05^{*}\right)$.

Sayed Hassan Mohamed (2019) and Farid Hammam Mohamed (2017) emphasize that there are specific specifications for certified artificial turf including grass length and density in order to avoid the risk of injuries caused by poor qualities.The current stadiums are illegal and insecure. (42: 2) (18: 33)

The researcher agrees with the opinion of the three research groups that the provision of units for dressing, toilets and various means of safety and security and the use of artificial turf certified internationally and set periodic maintenance dates, and work to provide technical requirements to reduce the risks caused by these stadiums.

While it is clear that there are statistically insignificant differences between the responses of the three research groups on the statement (43/2) for owners and employees, and corresponding (26/2) for officials and corresponding (23/2) for the beneficiaries where the responses of the groups of officials and beneficiaries came in an acceptable direction (77.78\%). (74.38\%), respectively, while the responses of the owners and staff of the stadiums went in an unacceptable direction (40.00\%), with a value of Chi (37.42).

Mohammed Abulaila (2018) asserts that the officials of the private stadiums must abide by legal procedures and obtain legal permits, and not violate the law. (30: 2)

The researcher attributes the opinion of the owners and staff of the stadiums to the fact that these stadiums were actually established and it is impossible to change this because it will cost them large sums of money to buy new land or demolition and renovation of the existing. 
Table (18): Comparison of results of iterations, percentages, Chi square, weighted percentage, average value and prevailing direction on the Second Axis for every two groups

\begin{tabular}{|c|c|c|c|c|c|c|c|c|c|c|c|c|c|c|c|c|c|}
\hline \multicolumn{3}{|c|}{ State. number } & \multirow[b]{3}{*}{ Statement } & \multicolumn{7}{|c|}{ 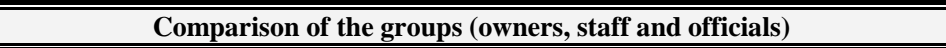 } & \multicolumn{7}{|c|}{ Comparison of the groups (owners, staff and beneficiaries) } \\
\hline \multirow{2}{*}{ 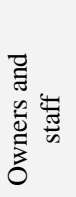 } & \multirow[b]{2}{*}{ 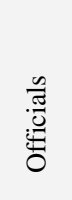 } & \multirow[b]{2}{*}{$\begin{array}{l}\stackrel{0}{0} \\
\stackrel{D}{0} \\
\infty\end{array}$} & & \multicolumn{3}{|c|}{ Owners and staff $=150$} & \multicolumn{3}{|c|}{ Officials $=27$} & \multirow[b]{2}{*}{$\begin{array}{l}\text { Chi } \\
\text { Sq. }\end{array}$} & \multicolumn{3}{|c|}{ Owners and staff $=150$} & \multicolumn{3}{|c|}{ Beneficiaries $=121$} & \multirow[b]{2}{*}{$\begin{array}{l}\text { Chi } \\
\text { Sq. }\end{array}$} \\
\hline & & & & $\begin{array}{c}\text { Approv. } \\
\text { rate }\end{array}$ & Direct. & $\begin{array}{c}\text { Weight. } \\
\text { ratio }\end{array}$ & $\begin{array}{l}\text { Approv. } \\
\text { rate }\end{array}$ & Direct. & $\begin{array}{l}\text { Weight. } \\
\text { ratio }\end{array}$ & & $\begin{array}{c}\text { Approv. } \\
\text { rate }\end{array}$ & Direct. & $\begin{array}{l}\text { Weight. } \\
\text { ratio }\end{array}$ & $\begin{array}{l}\text { Approv. } \\
\text { rate }\end{array}$ & Direct. & $\begin{array}{l}\text { Weight. } \\
\text { ratio }\end{array}$ & \\
\hline 47 & 29 & 26 & Youth attitudes towards investment business. & 94.00 & Yes & 97.00 & 85.19 & Yes & 92.59 & 2.61 & $9 \overline{94.00}$ & $\overline{\text { Yes }}$ & 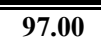 & 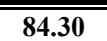 & 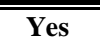 & 92.15 & 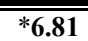 \\
\hline 48 & 30 & 27 & $\begin{array}{l}\text { The spread of unemployment among young people in } \\
\text { Egyptian society. }\end{array}$ & 88.00 & Yes & 94.00 & 81.48 & Yes & 90.74 & 0.86 & 88.00 & Yes & 94.00 & 88.43 & Yes & 94.21 & 0.01 \\
\hline 49 & 31 & 28 & An investment that drives young people to exercise. & 92.00 & Yes & 96.00 & 81.48 & Yes & 90.74 & 2.92 & 92.00 & Yes & 96.00 & 70.25 & Yes & 85.12 & $* 21.74$ \\
\hline 50 & 32 & 29 & High membership subscriptions for sports clubs. & 85.33 & Yes & 92.67 & 70.37 & Yes & 85.19 & 3.64 & 85.33 & Yes & 92.67 & 94.21 & Yes & 97.11 & $* 5.53$ \\
\hline 51 & 33 & 30 & Membership in some clubs and youth centers is closed. & 83.33 & Yes & 91.67 & 70.37 & Yes & 85.19 & 2.53 & 83.33 & Yes & 91.67 & 92.56 & Yes & 96.28 & $* 5.20$ \\
\hline 52 & 34 & 31 & High economic returns and profitability. & 95.33 & Yes & 97.67 & 85.19 & Yes & 92.59 & $* 4.04$ & 95.33 & Yes & 97.67 & 79.34 & Yes & 89.67 & *16.45 \\
\hline $53 / 1$ & $35 / 1$ & $32 / 1$ & Playing sports. & 82.00 & Yes & 91.00 & 81.48 & Yes & 90.74 & 0.00 & 82.00 & Yes & 91.00 & 66.12 & Yes & 83.06 & $* 8.99$ \\
\hline $53 / 2$ & $35 / 2$ & $32 / 2$ & spending spare time. & 82.00 & Yes & 91.00 & 77.78 & Yes & $\mathbf{8 8 . 8 9}$ & 0.27 & $\mathbf{8 2 . 0 0}$ & Yes & 91.00 & 66.12 & Yes & 83.06 & $* 8.99$ \\
\hline 54 & 36 & 33 & Decreased level of services in youth centers. & \begin{tabular}{|l|l|}
53.33 \\
\end{tabular} & Yes & 76.67 & 66.67 & Yes & 83.33 & 1.65 & 53.33 & Yes & 76.67 & 65.29 & Yes & 82.64 & $* 3.95$ \\
\hline 55 & 37 & 34 & $\begin{array}{l}\text { Absence of the supervisory role of the country on the } \\
\text { private stadiums (artificial turf). }\end{array}$ & 10.00 & No & 55.00 & 92.59 & Yes & 96.30 & $* 89.23$ & 10.00 & No & 55.00 & 61.98 & Yes & 80.99 & $* 81.59$ \\
\hline
\end{tabular}

Value of Chi square $(1,0.05)=3.841$ Weighted average: No $(1: 1.5)$, Yes $(1.6: 2)$

All statements of the axis and its dimension except those common to the three groups will be presented and discussed in the following table.

It is clear from Table (18) that there are statistically significant differences between the responses of the owners and staff of the stadiums and officials of the concerned authorities on the statements $(47,48,49,50,51,53 / 1,53 / 2,54)$ to the owners and staff of the stadiums and the corresponding statements $(29,30,31,32,33,35 / 1,35 / 2,36)$ for the concerned authorities, despite the agreement of the two research with a percentage ranging between (53.33: 94.00\%) (66.67: 85.19\%) respectively and the value of Chi (0.00: 3.64).

- It is clear that there are differences that are statistically insignificant between the responses of the groups of owners and employees and officials on the statement (52) for the owners and staff of the stadiums and the corresponding statement (34) where the responses of the two groups were in the acceptable direction $(95.33 \%)$ (85.19\%), respectively, with Chi (4.04).

- It is clear that there are differences that are statistically insignificant between the responses of the owners and employees and the group of officials about the statement (55) for the group of owners and employees of the stadiums and corresponding the statement (37) where the direction of the responses of owners and employees were unacceptable by $(10.00 \%)$, while the responses of the officials' were in the acceptable direction $(89.23 \%)$ and Chi $(96.30 *)$. 
- It is clear that there are statistically significant differences between the responses of owners, stadium staff and beneficiaries about the statements $(47,49,50,51,52,53 / 1,53 / 2,54)$ for the group of owners and staff of the stadiums and the corresponding statements $(26,28,29,30$, $31,32 / 1,32 / 2,33)$ for the beneficiaries in the concerned authorities, despite the agreement of the two groups of research with a percentage ranging (53.33: 95.33\%) (65.29: 94.21\%) respectively and the value of Chi (3.95: 21.74*).

- There are statistically significant differences between the responses of owners, stadium staff and beneficiaries on the statement (48) for the group of owners and staff of the stadiums and corresponds (27) for the category of beneficiaries in the concerned authorities, despite the agreement of the two research groups by $(88.00 \%)(88.43 \%)$, respectively and Chi $(0.01)$.

- It is also clear that there are differences that are statistically insignificant between the responses of owners, employees and beneficiaries on the statement (55) for the group of owners and employees of the stadiums and the corresponding statement (34), where the responses of the first groupin the direction of disagreement $(10.00 \%)$ and the second groupin the direction of agreement $(61.98 \%)$ respectively and Chi value $(81.59 *)$.

Table (19): Comparison of results of iterations, percentages, Chi square, weighted percentage, average value and prevailing direction on the Second Axis for all

\begin{tabular}{|c|c|c|c|c|c|c|c|c|c|c|c|c|c|}
\hline \multicolumn{3}{|c|}{ State. number } & \multirow[b]{2}{*}{ Statement } & \multicolumn{3}{|c|}{ Owners and staff $=150$} & \multicolumn{3}{|c|}{ Officials $=27$} & \multicolumn{3}{|c|}{ Beneficiaries = 121} & \multirow[b]{2}{*}{ Chi Sq. } \\
\hline 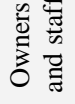 & 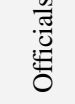 & 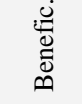 & & $\begin{array}{l}\text { Approv. } \\
\text { rate }\end{array}$ & Direct. & $\begin{array}{l}\text { Weight. } \\
\text { ratio }\end{array}$ & $\begin{array}{l}\text { Approv. } \\
\text { rate }\end{array}$ & Direct. & $\begin{array}{l}\text { Weight. } \\
\text { ratio }\end{array}$ & $\begin{array}{c}\text { Approv. } \\
\text { rate }\end{array}$ & Direct. & $\begin{array}{l}\text { Weight. } \\
\text { ratio }\end{array}$ & \\
\hline 47 & 29 & 26 & Youth attitudes towards investment business. & 94.00 & Yes & 97.00 & 85.19 & Yes & 92.59 & 84.30 & Yes & 92.15 & $* 7.09$ \\
\hline 48 & 30 & 27 & $\begin{array}{l}\text { The spread of unemployment among young } \\
\text { people in Egyptian society. }\end{array}$ & 88.00 & Yes & 94.00 & 81.48 & Yes & 90.74 & 88.43 & Yes & 94.21 & 1.03 \\
\hline 49 & 31 & 28 & An investment that drives youth to exercise. & 92.00 & Yes & 96.00 & 81.48 & Yes & 90.74 & 70.25 & Yes & 85.12 & ${ }^{*} 21.68$ \\
\hline 50 & 32 & 29 & High membership subscriptions for sports clubs. & 85.33 & Yes & 92.67 & 70.37 & Yes & 85.19 & 94.21 & Yes & 97.11 & ${ }^{*} 12.95$ \\
\hline 51 & 33 & 30 & $\begin{array}{l}\text { Membership in some clubs and youth centers is } \\
\text { closed. }\end{array}$ & 83.33 & Yes & 91.67 & 70.37 & Yes & 85.19 & 92.56 & Yes & 96.28 & ${ }^{*} 10.63$ \\
\hline 52 & 34 & 31 & High economic returns and profitability. & 95.33 & Yes & 97.67 & 85.19 & Yes & 92.59 & 79.34 & Yes & 89.67 & ${ }^{*} 16.34$ \\
\hline $53 / 1$ & $35 / 1$ & $32 / 1$ & Playing sports. & 82.00 & Yes & 91.00 & 81.48 & Yes & 90.74 & 66.12 & Yes & 83.06 & ${ }^{* 9.71}$ \\
\hline $53 / 2$ & $35 / 2$ & $32 / 2$ & spending spare time. & 82.00 & Yes & 91.00 & 77.78 & Yes & 88.89 & 66.12 & Yes & 83.06 & *9.16 \\
\hline 54 & 36 & 33 & Decreased level of services in youth centers. & 53.33 & Yes & 76.67 & 66.67 & Yes & 83.33 & 65.29 & Yes & 82.64 & 4.62 \\
\hline 55 & 37 & 34 & $\begin{array}{l}\text { Absence of the supervisory role of the country on } \\
\text { the private stadiums (artificial turf). }\end{array}$ & 10.00 & No & 55.00 & 92.59 & Yes & 96.30 & 61.98 & Yes & 80.99 & *112.91 \\
\hline
\end{tabular}

Value of Chi square $(2,0.05)=5.991$ Weighted average: No $(1: 1.5)$, Yes (1.6: 2). 
It is clear from Table (19) that there are statistically insignificant differences between the responses of the three research groups on the statements $(47,49,50,51,52,53 / 1,53 / 2)$ to the owners and employees and corresponding $(29,31,32,33,34,35 / 1,35 / 2)$ for officials and corresponding $(26,28,29,30,31,32 / 1,32 / 2)$ for the beneficiaries where responses to all came in an acceptable direction between (82.00: 95.33\%) (70.37:85.19\%)(66.12:94.21\%) and the value of Chi ranged from (7.09: $21.68 *)$.

Abdul Hadi Sobhi Mohammed (2017) points out that these stadiums contribute to the youth's constant exercise of their hobbies, especially those who do not always find available stadiums. (1:2)

The researcher agrees with these results, where investment in sports is considered one of the best emerging fields that provide significant financial gains.

It is also clear that there are statistically significant differences between the responses of the three research groups on the statements (48, 54) to the owners and employees and corresponding $(30,36)$ to the officials and corresponding $(27,33)$ to the beneficiaries where the responses for all groups came in an acceptable direction ranging between $(53.33: 88.43 \%)$ and the value of Chi (1.03: 4.6).

Sayed Hassan Mohamed (2019) asserts that these stadiums resulted from attempts to search for alternatives to youth centers as their stadiums were large sandy playgrounds or dirt which may lead to various injuries, and it is the only source for many young people who do not find the place to exercise. (42:2)

The researcher agrees with the results of the two statements, where the complexity of competition by young people and their inability to work in large projects led to the high unemployment rate and turned to work in small projects such as the establishment of private stadiums.

There are statistically insignificant differences between the groups of research on the statement (55) for owners and employees and corresponds to (37) for officials and (27) for beneficiaries where the responses to the group of owners and employees went in an unacceptable direction by $(10.00 \%)$, while responses were acceptable for officials and beneficiaries by $(92.59 \%)(61.98 \%)$ and Chi value was $(112.91 *)$.

Haitham al-Taba'i Mahmoud (2011) also stressed that private stadiums are a phenomenon that provides an opportunity to play football at reasonable prices, and that there is no supervisory body on it. (22: 2)

The researcher agrees with the results of the statement because the delay of the country in the issuance of laws, regulations and requirements for the establishment of these private stadiums led to the conceptualization and design without adherence to any conditions or restrictions and considers governance to be an important role in reducing risks through the availability of a control system. 
Table (20): Comparison of results of iterations, percentages, Chi square, weighted percentage, average value and prevailing direction on the Third Axis for every two groups

\begin{tabular}{|c|c|c|c|c|c|c|c|c|c|c|c|c|c|c|c|c|c|}
\hline \multicolumn{3}{|c|}{ State. number } & \multirow{3}{*}{ Statement } & \multicolumn{7}{|c|}{ Comparison of the groups (owners, staff and officials) } & \multicolumn{7}{|c|}{ Comparison of the groups (owners, staff and beneficiaries) } \\
\hline \multirow[b]{2}{*}{ 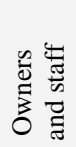 } & \multirow[b]{2}{*}{ 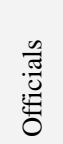 } & \multirow[b]{2}{*}{ 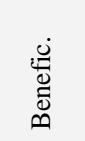 } & & \multicolumn{3}{|c|}{ Owners and staff $=150$} & \multicolumn{3}{|c|}{ Officials $=27$} & \multirow[b]{2}{*}{$\begin{array}{l}\text { Chi } \\
\text { Sq. }\end{array}$} & \multicolumn{3}{|c|}{ Owners and staff $=150$} & \multicolumn{3}{|c|}{ Beneficiaries $=121$} & \multirow[b]{2}{*}{ Chi Sq. } \\
\hline & & & & $\begin{array}{l}\text { Approv. } \\
\text { rate }\end{array}$ & Direct. & $\begin{array}{l}\text { Weight. } \\
\text { ratio }\end{array}$ & $\begin{array}{l}\text { Approv. } \\
\text { rate }\end{array}$ & Direct. & $\begin{array}{l}\text { Weight. } \\
\text { ratio }\end{array}$ & & $\begin{array}{l}\text { Approv. } \\
\text { rate }\end{array}$ & Direct. & $\begin{array}{l}\text { Weight. } \\
\text { ratio }\end{array}$ & $\begin{array}{l}\text { Approv. } \\
\text { rate }\end{array}$ & Direct. & $\begin{array}{l}\text { Weight. } \\
\text { ratio }\end{array}$ & \\
\hline $\begin{array}{c}1 / 1 \\
56\end{array}$ & $\begin{array}{c}/ 1 / 1 \\
38\end{array}$ & $35 / 1 / 1$ & Surveillance Cameras. & 82.00 & Yes & 91.00 & 100 & Yes & 100 & *5.73 & 82.00 & Yes & 91.00 & 82.64 & Yes & 91.32 & 0.02 \\
\hline $\begin{array}{c}/ 1 / 2 \\
56\end{array}$ & $\begin{array}{l}1 / 2 \\
38\end{array}$ & $35 / 1 / 2$ & Fire alarm. & 78.00 & Yes & 89.00 & 92.59 & Yes & 96.30 & 3.07 & 78.00 & Yes & 89.00 & 82.64 & Yes & 91.32 & 0.91 \\
\hline $\begin{array}{c}12 / 1 \\
56\end{array}$ & $\begin{array}{c}30 \\
12 / 1 \\
38\end{array}$ & $35 / 2 / 1$ & $\begin{array}{l}\text { Players and each other during sports } \\
\text { activites. }\end{array}$ & $\mathbf{5 9 . 3 3}$ & Yes & 79.67 & 85.19 & Yes & 92.59 & $* 6.58$ & 59.33 & Yes & 79.67 & 67.77 & Yes & 83.88 & 2.05 \\
\hline $\begin{array}{c}12 / 2 \\
56\end{array}$ & $\begin{array}{l}12 / 2 \\
38\end{array}$ & $35 / 2 / 2$ & Fans against their team or opposing team. & 60.67 & Yes & 80.33 & 77.78 & Yes & 88.89 & 2.88 & 60.67 & Yes & 80.33 & 67.77 & Yes & 83.88 & 1.46 \\
\hline $56 / 3$ & $38 / 3$ & $35 / 3$ & $\begin{array}{l}\text { Spread of noise due to disturbing sounds and } \\
\text { proximity to residential areas. }\end{array}$ & 40.00 & No & 70.00 & 70.37 & Yes & 85.19 & $* 8.54$ & 40.00 & No & 70.00 & 66.94 & Yes & 83.47 & *19.48 \\
\hline $56 / 4$ & $38 / 4$ & $35 / 4$ & $\begin{array}{l}\text { The stadiums are not managed by specialists } \\
\text { who are scientifically and practically } \\
\text { qualified. }\end{array}$ & 38.00 & No & 69.00 & $\mathbf{7 4 . 0 7}$ & Yes & 87.04 & $* 12.12$ & $\mathbf{3 8 . 0 0}$ & No & 69.00 & 94.21 & Yes & 97.11 & $* 90.90$ \\
\hline $56 / 5$ & $38 / 5$ & $35 / 5$ & $\begin{array}{l}\text { The number of staff operating the stadiums } \\
\text { is insufficient. }\end{array}$ & 40.67 & No & 70.33 & 66.67 & Yes & 83.33 & $* 6.26$ & 40.67 & No & 70.33 & 92.56 & Yes & 96.28 & $* 78.13$ \\
\hline $56 / 6$ & $38 / 6$ & $35 / 6$ & $\begin{array}{l}\text { The lack of a medical unit or a doctor within } \\
\text { the facilities associated with the project. }\end{array}$ & 94.00 & Yes & 97.00 & 74.07 & Yes & 87.04 & $* 11.05$ & 94.00 & Yes & 97.00 & 73.55 & Yes & 86.78 & *21.81 \\
\hline $56 / 7$ & $38 / 7$ & $35 / 7$ & $\begin{array}{l}\text { Lack of periodic maintenance of artificial } \\
\text { turf. }\end{array}$ & 20.00 & No & 60.00 & 85.19 & Yes & 92.59 & $* 46.35$ & 20.00 & No & 60.00 & 79.34 & Yes & 89.67 & *94.80 \\
\hline $56 / 8$ & $38 / 8$ & $35 / 8$ & $\begin{array}{l}\text { Maintenance is not carried out by competent } \\
\text { authorities. }\end{array}$ & 10.00 & No & $\mathbf{5 5 . 0 0}$ & 85.19 & Yes & 92.59 & *76.72 & 10.00 & No & $\mathbf{5 5 . 0 0}$ & 76.03 & Yes & 88.02 & $\begin{array}{c}122.22 \\
*\end{array}$ \\
\hline $56 / 9$ & $38 / 9$ & $35 / 6$ & $\begin{array}{l}\text { Lack of attention to care for the talented } \\
\text { athletes on the country level. }\end{array}$ & 93.33 & Yes & 96.67 & 74.07 & Yes & 87.04 & $* 9.78$ & 93.33 & Yes & 96.67 & 61.98 & Yes & 80.99 & $* 40.15$ \\
\hline $57 / 1$ & $39 / 1$ & $36 / 1$ & $\begin{array}{l}\text { Erosion of agricultural land, which poses a } \\
\text { greater risk to agricultural land. }\end{array}$ & 33.33 & No & 66.67 & 100 & Yes & 100 & $* 41.38$ & 33.33 & No & 66.67 & 99.17 & Yes & 99.59 & $\begin{array}{c}124.18 \\
*\end{array}$ \\
\hline $57 / 2$ & $39 / 2$ & $36 / 2$ & $\begin{array}{l}\text { Effect on lighting transformers due to high } \\
\text { usage in the area. }\end{array}$ & 26.67 & No & 63.33 & 96.30 & Yes & 98.15 & $* 47.44$ & 26.67 & No & 63.33 & 91.74 & Yes & 95.87 & $\begin{array}{c}114.93 \\
*\end{array}$ \\
\hline $57 / 3$ & $39 / 3$ & $36 / 3$ & $\begin{array}{l}\text { The negative impact on the health of } \\
\text { practitioners due to the large number of } \\
\text { injuries to the nature of artificial turf. }\end{array}$ & 12.67 & No & 56.33 & 85.19 & Yes & 92.59 & $* 66.49$ & 12.67 & No & 56.33 & 82.64 & Yes & 91.32 & $\begin{array}{c}133.16 \\
*\end{array}$ \\
\hline $57 / 4$ & $39 / 4$ & $36 / 4$ & $\begin{array}{l}\text { The seriousness of the injuries resulting } \\
\text { from the private stadiums (artificial turf). }\end{array}$ & 16.00 & No & $\mathbf{5 8 . 0 0}$ & 81.48 & Yes & 90.74 & *51.01 & 16.00 & No & 58.00 & 90.08 & Yes & 95.04 & $\begin{array}{c}147.08 \\
*\end{array}$ \\
\hline $57 / 5$ & $39 / 5$ & $36 / 5$ & $\begin{array}{l}\text { Spread of cafeterias on the side of the } \\
\text { stadiums without a health certificate to } \\
\text { practice this activity. }\end{array}$ & 6.67 & No & 53.33 & $\mathbf{7 4 . 0 7}$ & Yes & 87.04 & *73.86 & 6.67 & No & $\mathbf{5 3 . 3 3}$ & 72.73 & Yes & 86.36 & $\underset{*}{126.61}$ \\
\hline
\end{tabular}

Value of Chi square $(1,0.05)=3.841$ Weighted average: No (1: 1.5), Yes (1.6: 2). 
All statements of the axis and its dimension except those common to the three groups will be presented and discussed in the following table.

It is also clear from Table (20) that there are statistically significant differences between the responses of the owners and staff of the stadiums and the group of officials on the statements $(56 / 1 / 2,56 / 2 / 2)$ to the owners and staff of the stadiums and corresponding to $(38 / 1 / 2,38 / 2 / 2)$ for the group of officials, despite the agreement of the two research groups with a percentage ranging (60.67: 78.00 \%) (77.78: 92.59\%) respectively and came the value of Chi (3.07: 2.88).

- It is also clear that there are statistically insignificant differences between the responses of the groups of owners and employees and officials for the statements $(56 / 3,56 / 4,56 / 5,56 / 7,56 / 8,57 / 1,57 / 2,57 / 3,57 / 4,57 / 5)$ for owners and staff of the stadiums and corresponds to statements $(38 / 3,38 / 4,38 / 5,38 / 7,38 / 8,39 / 1,39 / 2,39 / 3,39 / 4,39 / 5)$. The responses of the first group in an unacceptable direction ranged between (4.00: $6.67 \%)$ and the second group in agreement with (66.67: 100\%) respectively with a value of Chi (6.26: 76.72).

- It is also clear that there are statistically insignificant differences between the responses of the owners and stadium staff and the officials of the concerned authorities regarding the statements $(56 / 1 / 1,56 / 2 / 1,56 / 6,56 / 9)$ for the owners and staff of the stadiums and the corresponding statements $(38 / 1 / 1,38 / 2 / 1,38 / 6,38 / 9)$ to the officials of the concerned authorities where the responses of the two groups came in an acceptable direction by (59.33: 94.00\%) (74.07: 100\%) respectively and the value of Chi (5.73: 11.05).

- As can be seen from the table, there are statistically significant differences between the responses of the owners and stadium staff and the beneficiaries category on the statements $(56 / 1 / 1,56 / 1 / 2,56 / 2 / 1,56 / 2 / 2)$ for the owners and staff of the stadiums and corresponds to them $(35 / 1 / 1,35 / 1 / 2,35 / 2 / 1,35 / 2 / 2)$ for the beneficiaries groupin the concerned authorities despite the agreement of the two research groups with a percentage ranging from (59.33: 82.00\%) (67.77: 82.64\%) respectively and the value of Chi (0.02: 2.05).

- It is also clear that there are differences that are statistically insignificant between the responses of the categories of owners and employees and beneficiaries group on the statements $(56 / 3,56 / 4,56 / 5,56 / 7,56 / 8,57 / 1,57 / 2,57 / 3.57 / 4,57 / 5)$ for owners and staff of the stadiums and corresponds to statements $(35 / 3,35 / 4,35 / 5,35 / 7,35 / 8,36 / 1,36 / 2,36 / 3,36 / 4,36 / 5)$. The responses of the first group were in an unacceptable direction ranging between (6.67: 40.00\%) and the second group with agreement (66.94: 99.17\%) respectively with a value of Chi (19.48: 147.08 *).

- It is also clear that there are statistically insignificant differences between the responses of owners, stadium staff and beneficiaries on the statements $(56 / 6,56 / 9)$ to the owners and staff of the stadiums and the corresponding statements $(35 / 6,35 / 9)$ to the beneficiaries where the responses of the two groups were acceptable by (93.33: 94.00\%) (61.98: 73.55\%), respectively, and the value of Chi (21.81: 40.15). 
Table (21): Comparison of results of iterations, percentages, Chi square, weighted percentage, average value and prevailing direction on the Third axis for all groups

\begin{tabular}{|c|c|c|c|c|c|c|c|c|c|c|c|c|c|}
\hline \multicolumn{3}{|c|}{ State. number } & \multirow[b]{2}{*}{ Statement } & \multicolumn{3}{|c|}{ Owners and staff $=150$} & \multicolumn{3}{|c|}{ Officials $=\mathbf{2 7}$} & \multicolumn{3}{|c|}{ Beneficiaries $=121$} & \multirow[b]{2}{*}{ Chi Sq } \\
\hline 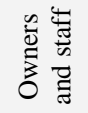 & 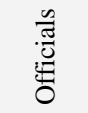 & 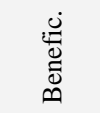 & & $\begin{array}{c}\text { Approv. } \\
\text { rate }\end{array}$ & Direct. & $\begin{array}{c}\text { Weight. } \\
\text { ratio }\end{array}$ & $\begin{array}{c}\text { Approv. } \\
\text { rate }\end{array}$ & Direct. & $\begin{array}{c}\text { Weight. } \\
\text { ratio }\end{array}$ & $\begin{array}{c}\text { Approv. } \\
\text { rate }\end{array}$ & Direct. & $\begin{array}{c}\text { Weight. } \\
\text { ratio }\end{array}$ & \\
\hline $56 / 1 / 1$ & $38 / 1 / 1$ & $35 / 1 / 1$ & Surveillance Cameras. & 82.00 & Yes & 91.00 & 100 & Yes & 100 & 82.64 & Yes & 91.32 & 5.72 \\
\hline $56 / 1 / 2$ & $38 / 1 / 2$ & $35 / 1 / 2$ & Fire alarm . & 78.00 & Yes & 89.00 & 92.59 & Yes & 96.30 & 82.64 & Yes & 91.32 & 3.47 \\
\hline $56 / 2 / 1$ & $38 / 2 / 1$ & $35 / 2 / 1$ & Players and each other during sports activites. & 59.33 & Yes & 79.67 & 85.19 & Yes & 92.59 & 67.77 & Yes & 83.88 & ${ }^{*} 7.37$ \\
\hline $56 / 2 / 2$ & $38 / 2 / 2$ & $35 / 2 / 2$ & Fans against their team or opposing team. & 60.67 & Yes & 80.33 & 77.78 & Yes & 88.89 & 67.77 & Yes & 83.88 & 3.59 \\
\hline $56 / 3$ & $38 / 3$ & $35 / 3$ & $\begin{array}{l}\text { Spread of noise due to disturbing sounds and proximity to } \\
\text { residential areas. }\end{array}$ & 40.00 & No & 70.00 & 70.37 & Yes & 85.19 & 66.94 & Yes & 83.47 & ${ }^{* 22.87}$ \\
\hline $56 / 4$ & $38 / 4$ & $35 / 4$ & $\begin{array}{l}\text { The stadiums are not managed by specialists who are } \\
\text { scientifically and practically qualified. }\end{array}$ & 38.00 & No & 69.00 & 74.07 & Yes & 87.04 & 94.21 & Yes & 97.11 & ${ }^{* 93.25}$ \\
\hline $56 / 5$ & $38 / 5$ & $35 / 5$ & The number of staff operating the stadiums is insufficient. & 40.67 & No & 70.33 & 66.67 & Yes & 83.33 & 92.56 & Yes & 96.28 & ${ }^{*} 78.46$ \\
\hline $56 / 6$ & $38 / 6$ & $35 / 6$ & $\begin{array}{l}\text { The lack of a medical unit or a doctor within the facilities } \\
\text { associated with the project. }\end{array}$ & 94.00 & Yes & 97.00 & 74.07 & Yes & 87.04 & 73.55 & Yes & 86.78 & ${ }^{*} 22.84$ \\
\hline $56 / 7$ & $38 / 7$ & $35 / 7$ & Lack of periodic maintenance of artificial turf. & 20.00 & No & 60.00 & 85.19 & Yes & 92.59 & 79.34 & Yes & 89.67 & ${ }^{*}$ 109.03 \\
\hline $56 / 8$ & $38 / 8$ & $35 / 8$ & Maintenance is not carried out by competent authorities. & 10.00 & No & 55.00 & 85.19 & Yes & 92.59 & 76.03 & Yes & 88.02 & ${ }^{*} 139.60$ \\
\hline $56 / 9$ & $38 / 9$ & $35 / 9$ & $\begin{array}{l}\text { Lack of attention to care for the talented athletes on the } \\
\text { country level. }\end{array}$ & 93.33 & Yes & 96.67 & 74.07 & Yes & 87.04 & 61.98 & Yes & 80.99 & ${ }^{*} 39.89$ \\
\hline $57 / 1$ & $39 / 1$ & $36 / 1$ & $\begin{array}{l}\text { Erosion of agricultural land, which poses a greater risk to } \\
\text { agricultural land. }\end{array}$ & 33.33 & No & 66.67 & 100 & Yes & 100 & 99.17 & Yes & 99.59 & ${ }^{*} 144.80$ \\
\hline $57 / 2$ & $39 / 2$ & $36 / 2$ & $\begin{array}{l}\text { Effect on lighting transformers due to high usage in the } \\
\text { area. }\end{array}$ & 26.67 & No & 63.33 & 96.30 & Yes & 98.15 & 91.74 & Yes & 95.87 & ${ }^{*} 134.34$ \\
\hline $57 / 3$ & $39 / 3$ & $36 / 3$ & $\begin{array}{l}\text { The negative impact on the health of practitioners due to } \\
\text { the large number of injuries to the nature of artificial turf. }\end{array}$ & 12.67 & No & 56.33 & 85.19 & Yes & 92.59 & 82.64 & Yes & 91.32 & ${ }^{*} 148.25$ \\
\hline $57 / 4$ & $39 / 4$ & $36 / 4$ & $\begin{array}{l}\text { The seriousness of the injuries resulting from the private } \\
\text { stadiums (artificial turf). }\end{array}$ & 16.00 & No & 58.00 & 81.48 & Yes & 90.74 & 90.08 & Yes & 95.04 & $*^{*} 157.60$ \\
\hline $57 / 5$ & $39 / 5$ & $36 / 5$ & $\begin{array}{l}\text { Spread of cafeterias on the side of the stadiums without a } \\
\text { health certificate to practice this activity. }\end{array}$ & 6.67 & No & 53.33 & 74.07 & Yes & 87.04 & 72.73 & Yes & 86.36 & ${ }^{*} 136.95$ \\
\hline
\end{tabular}

Value of Chi square $(2,0.05)=5.991$ Weighted average: No $(1: 1.5)$, Yes $(1.6: 2)$ 
It is clear from Table (21) that there are statistically significant differences between the responses of the three research groups on the statements $(56 / 1 / 1,56 / 1 / 2,56 / 2 / 2)$ for the owners and employees and corresponding (38/1/1, 38/1/2, 38/2/2) for officials and corresponding (28/1/1, 28/1/2, 28/2/2) for the beneficiaries, where the responses of all groups came in an acceptable direction ranging between (60.67: 82.00\%) (77.78: 100\%), (67.77: 82.64) and the value of Chi (3.47: 5.72).

Manar Fikri Okasha, Undersecretary of the Ministry of Youth and Sports in Menia (2018), asserts that private stadiums violate the law, as they are in violation of the Building Law (119), in addition to being considered as encroachments on the agricultural area, as well as using electricity and lighting in different ways. (29:2)

The researcher agrees with the results of the statements as the lack of security means such as surveillance cameras, which have a significant role in the governance of the risks that prevents the activity, and also a fire alarm system to control and deal with any risks and limit its development.

It is also clear that there are differences that are statistically insignificant between the responses of the research sample on the statements (56/2/1, $56 / 6,56 / 9)$ for the owners and employees and corresponds $(38 / 2 / 1,38 / 6,38 / 9)$ for officials and corresponds $(35 / 2 / 1,35 / 6,35 / 9)$ to the beneficiaries where the responses for all came acceptable that ranged between (59.33: 94.00) and the value of Chi (7.37: 39.89).

Ahmed Al-Sharif (2018) emphasized that the government is increasingly aware of the importance of sports organizations relying on the implementation of governance, which in turn reduces risks. (6: 60)

The researcher attributes the riots and violence to the different cultures and behavior of individuals since they are from different environments, and it is clear that the lack of people with the ability to select the talented, this leads to the atrophy of their talent as the main goal of the establishment of these stadiums is the financial gain.

It is also evident that there are statistically insignificant differences between the groups on statements $(56 / 3,56 / 4,56 / 5,56 / 7,56 / 8,57 / 1,57 / 2$, $57 / 3,57 / 4,57 / 5)$ for owners and employees and corresponding (38/3, 38/4, 38/5, 38/7, 38/8, 39/1, 39/2, 39/3, 39/4, 39/5) for officials and corresponding $(35 / 3,35 / 4,35 / 5,35 / 7,35 / 8,36 / 1,36 / 2,36 / 3,36 / 4,36 / 5)$ for beneficiaries with disagreement for owners and staff group ranged between (6.67: 40.00\%) while the responses went in the direction of agreement for officials and beneficiaries (66.67: 100\%) (66.94: $99.17 \%)$ as the value of Chi $(22.87: 157.60 *)$.

Ben Ali Belaouzouz Hassan et al. (2012) and the results of the study of Mahmoud Gamal Mohamed (2012) (28) emphasized that the lack of specialized human resources among sports project workers is one of the main negatives that are reflected in the level of performance. (14:19) Ahmed Al-Sharif (2018) pointed out that governance is a key input in the discipline and improvement of performance in various organizations, where transparency and accountability are one of the most important approaches to achieving this (6: 136)

The researcher disagrees with the results of the owners of private stadiums, where it is necessary to take governence elements into account when establishing private stadiums to govern the various risks that may be caused by them.

In light of the above, the researcher presented and discussed all the axes related to the objectives of the research which has answered all of the questions without exception 


\section{Conclusions and Recommendations:}

\section{Conclusions:}

In the light of the findings of the researcher, the following conclusions were drawn:

First axis: Identifing the current status of governance of the risks of the spread of private stadiums (Artificial turf) in the Arab Republic of Egypt:

\section{First dimension: Administrative components:}

- There is no plan based on scientific basis to ensure the functioning of the private stadiums.

- There is no organizational structure for all employees in the private stadiums (artificial turf) to determine the channels of communication.

- There is no regulatory guide that includes the objectives of the private stadiums, the organizational structure of the stadiums, and the different responsibilities and competencies of the staff.

- The private stadiums (artificial turf) are not subject to the direct supervision of the Ministry of Youth and Sports, and there is no obligation to maintain the use of the land as allocated to it according to the local plan.

- The private stadiums do not comply with the building requirements and health specifications.

\section{Second dimension: Legal components:}

- There are no appropriate legal frameworks for the establishment of private stadiums by the Ministry of Youth and Sports and there are legal procedures by agricultural associations for the establishment of private stadiums.

- There are no legal formulas concluded between the project owner and the Ministry of Youth and Sports.

- Officials will adhere to secure the country's right to public utilities, water, electricity and taxes.

- There are no internal regulations for the management of labor in private stadiums (artificial turf).

\section{Third dimension: Financial, human and information components:}

- No budgets are allocated by the Ministry of Youth and Sports to implement and support the project.

- There is no website for the private stadiums (Artificial turf) to market its various activities.

- Market research is not conducted on the needs and requirements of beneficiaries and their satisfaction with the services.

- The most attending groups are students of institutes and university students, and the target age group for the establishment of private stadiums is less than 18 years, 18-35 years, 36 and above.

- The quality of services provided in the stadiums for sports academies and the establishment of Ramadan sessions.

- The most attractive season to practice is summer, then autumn, then winter. 


\section{Fourth dimension: Technical components:}

- The organization responsible for the design of the private stadiums is not the Ministry of Health or the Ministry of Agriculture or the General Authority and that the Ministry responsible is the Ministry of Youth and Sports.

- Technical and legal conditions will be complied with when applying for licenses.

Second axis: Reasons for the spread of private stadiums (artificial turf) in the Arab Republic of Egypt:

The reasons for the spread of private stadiums are:

- Attitude of youth towards investment business, high economic returns and profitability.

- The spread of unemployment among young people in Egyptian society.

Third axis: Dangers of the spread of private stadiums (artificial turf) in the Arab Republic of Egypt:

* Factors that lead to the spread of the risks of private stadiums are:

- Lack of security means in the stadiums and are represented by surveillance cameras, fire alarm, violence and riot fans against their team or the opposing team.

- Not carrying out periodic maintenance for the artificial grass, and the maintenance process is not done by competent authorities.

* The risks arising from the spread of private stadiums are:

- The erosion of the agricultural area, which represents a greater danger to agricultural land.

- The negative impact on the health of practitioners due to the large number of injuries due to the nature of artificial grass.

\section{Recommendations:}

- Establishing a supervisory unit within the Ministry of Youth and Sports to monitor and follow up the administrative, legal, technical, financial, human and informational controls at the private stadiums (artificial turf).

- Spreading a culture of governance among all employees of private stadiums (artificial turf) to reduce the risk of spread.

- Providing a database on all the stadiums (artificial turf) at the level of Alexandria Governorate, to ensure transparency and disclosure can be easily accessed, with a commitment to provide clear information to the concerned authorities.

- Develop a code of ethics that includes the most important values and principles that all employees of the private stadiums should follow (artificial turf).

- - Develop a clear and specific job description for all employees of the private stadiums (artificial turf).

- Issuing legislation to the Ministry of Agriculture that allows it to remove violating establishments on the Republic level to preserve the agricultural area.

- Preparation and submission of periodic reports by officials of private stadiums (artificial turf) on the level of performance of the Ministry of Youth and Sports. 
- Providing security and safety factors inside the private stadiums (artificial turf).

- Strengthening channels of communication between the private stadiums (artificial turf) with the Directorate of Youth and Sports to reduce its risks.

- Establishing mechanisms of internal audits for private stadiums (artificial turf) to ensure the effectiveness of the role of observers.

\section{References:}

1- Abdel Hady Sobhy Mohamed (2017): Private Stadiums between Rationing and Removal (Youth Centers for All, Wlad El Balad Newspaper), July 10. https://soutalomma.com

2- Abdel Rahim Mohammed Abu Shama (2019): Collecting the Country's right to legalize land and remove building violations, Al Wafd Newspaper, Tuesday, June 11.

3- Abdullah Abdullatif Abdullah (2017): Principles of Corporate Governance (Disclosure and Transparency), Dar Al-Maarfa wa Al-Mostkabaal, Jordan.

4- Adel Abdel Rahman Ahmed (2003): An analytical and applied study of the concept of corporate governance and its applicability in joint stock companies operating in the Egyptian environment, Journal of Business Studies and Research, Zagazig University, Banha, twenty-third year, the first issue.

5- Adel Kamal El Din Ali (2015): Risk Management of Promotional Sports Activities in Student City, Port Said University, Unpublished Master Thesis, Faculty of Physical Education, Port Said University.

6- Ahmed El-Sherif (2018): Sport and Governance: The Global Approach to the Performance of Sports Organizations, 1st ed., Dar Al-Fikr, Cairo.

7- Ahmed Farid Hassan (2017): Rules and Prohibitions of Exercise in Ramadan, Dar Al-Shoaa for Publishing and Distribution, Cairo.

8- Al-Youm Al-Sabe'a Newspaper (2017): Published article entitled "Artificial Grass a Time Bomb", Monday (30) January.

9- Alaa Eldin Mohamed Sayed (2012): A Proposed Risk Management Plan in the Egyptian Weightlifting Federation, Unpublished Master Thesis, Faculty of Physical Education, Assiut University.

10- Archambeault , Deborah S(2002): Archambeault, Deborah S,"The relation between Corporate Governance Strength and Fraudulent Financial Reporting: Evidence from SEC Enforcement Cases" ,Nov.

11- Australian Sports Commission (2004): Athletics Review, Re-creating a culture for athletics in Australia, A report into the high performance, development and governance of athletics in Australia ,July .

12- Australian Sports Commission (2011): The Role of the Board in Building Strategic Capability :Towards an Integrated Model of Sport Governance Research"

13- Bashiti ,Lubna, Aram, (2009): Assessing Corporate Governance in Jordan, The Arab Bank Review, Vol . 8 , No. 1.

14- Ben Ali Belaouzouz Hassan, Abdelkarim Kandoura, Abdel Razzaq Habbar (2012): Risk Management, 1st Edit. , Warraq Publishing and Distribution, Jordan.

15- CIPE (2018): A Guide for Establishing Corporate Governance in Emerging Markets. www.cipe-arabia.org/pdfhelp.asp

16- Eman Mohamed Nasr El-Gamal (2011): Corporate Governance and its Role in Confronting the phenomenon of Economic Intransigence with Special Reference to Egypt, Scientific Journal of Economics and Trade, No. 4, October, Volume III, Faculty of Commerce, Ain Shams University.

17- Ezz El-Din Darwish Mohamed Ahmed (2012): Proposed plan for insurance 
against the risks of water sports in the Arab Republic of Egypt, unpublished Master Thesis, Faculty of Physical Education, Assiut University.

18- Fareed Hammam Mohammed (2017): Maintenance and Operation in Organizations, Shuaa Publishing and Distribution Center, Amman.

19- Fatma Fahad Khalil Al-Mozain (2017): Introduction to activating the role of internal audit in the application of governance process and enhancing the performance of risk management, a field study applied to companies listed on the Kuwaiti stock market, unpublished master thesis, Faculty of Commerce, Helwan University.

20- Glasgow ,Daved . B. (2008): "Corporate Governance's Time for Change public and private Measures ", Chemical Market Report , August, cited on 1 Fed , 2008, www.findarticles.com.

21- Hassan Bashir Mohamed (2018): Sports Management and its Applications, Shuaa Center for Publishing and Distribution, Cairo.

22- Haytham Al-Taba'i Mahmoud (2011): Private stadiums are a new phenomenon that entices the Egyptians, Al-Sharq Al-Awsat Newspaper, issue (11900), Tuesday 25 June.

23- Ibrahim El-Esawy Ibrahim (2003): Development in a Changing World: The Concept of Development and its Indicators, Dar El-Shorouk, Cairo.

24- Ibrahim Marzouk Mohamed (2002): The Sports Encyclopedia, 1st Edition, AlDaar Al-Sakafya for Publishing, Cairo.

25- Ibrahim Mohamed Abu Seada (2009): The Impact of Implementing the Concept of Governance in the ICT Sector on Human Resources Management Strategies, First International Conference on Corporate Governance: Current Practices and Future Prospects Faculty of Administrative and Financial Sciences, King Khalid University, Ministry of Higher Education, Saudi Arabia.

26- Jalal Al-Abed Hussein (2015): Corporate Governance What does it mean? The Implications for the Capital Market, Dar Al Rabie Publishing, Cairo.

27- Kefaya Abbadi (2018): Legal spaces for private football stadiums, Grass Egypt newspaper, 24 January. https://www.grassegypt.com

28- Mahmoud Gamal Mohamed (2012): Obstacles to the establishment of bot sports projects, unpublished Master Thesis, Department of Sports Management, Faculty of Physical Education, Mansoura University.

29- Manar Fekry Okasha (2018): An article titled "Private Stadiums as a New Way to Damage Farmland under the Guise of Youth Service, Saturday, October 27, AlMujaz Newspaper. https://www.elmogez.com

30- Mohamed Abou Laila (2016): Masrawy newspaper published an article entitled "Stadiums without a license draining its players" on Tuesday 16 August. https://www.masrawy.com

31- Mohamed Khalid Al-Mahayni (2007): A Practical Analytical Study titled Corporate Governance and its Importance in Attracting Investments and Developing Human Resources, Scientific Journal of Syrian Association of Certified Public Accountants, Second Issue, June, Saudi Arabia

32- Mohamed Mostafa Soliman (2006): Corporate Governance and Addressing Financial and Administrative Corruption, University publishing, Egypt.

33- Mohamed Saad Farid (2015): How to get a tax card (Methods and steps), AlFares Center, Cairo.

34- Mohamed Saad Mohamed Abdel Kader (2015): Some suggested insurance methods against the risks of artistic gymnastics in the Arab Republic of Egypt, an unpublished Master Thesis, Faculty of Physical Education, Assiut University. 
35- Mohamed Sobhy Hassan (2019): Al-Youm Al-Sabe 'Newspaper, published article entitled "Cairo Review of the decision to remove (2500) private stadiums", Wednesday 10 July. https://m.youm7.com/story.

36- Mohsen Ahmed El-Khudairy (2005): Corporate Governance, Dar El Salam Publishing, Cairo.

37- Nevin Gamea Hassan (2019): Seminar of the Small and Medium Enterprises Authority, Al-Youm Al-Sabea, September 12. https://www.youm7.com

38- Noura Mohammed Al-Shamri (2011): Activating the Role of Audit Committees and Governance Rules in Reducing Financial Risks in Kuwaiti Financial Banks, Scientific Journal of Commercial Research and Studies, No. 2, Part II, Helwan University.

39- Osama Said Abdel-Sadek, and Osama Hanafi Mahmoud (2009): Governance of the management of insurance companies, an integrated approach to a balanced strategic performance, the scientific journal, trade and finance, Volume II, second issue, Faculty of Commerce, Tanta University.

40- Salem Saeed Baajajah (2009): Principles of Corporate Governance and their Applicability to Saudi Joint Stock Companies, First International Conference on Corporate Governance: Current Practices and Future Prospects 12-13 Dhu al-Qa'da $1430 \mathrm{AH}$, corresponding to 31 October - 1 November, Center for Corporate Governance, College of Administrative and Financial Sciences, King Khalid University, Ministry of Higher Education, Saudi Arabia.

41- Samir Ali Ibrahim (2011): The most common sports injuries among football players of Premier League clubs in Khartoum State, unpublished Master Thesis, Training Department, Faculty of Physical Education, Khartoum

42- Sayed Hassan Mohamed (2019): Private football stadiums between licensing and quality, Al-Ahram Gate, Friday 13 September. https://gate.ahram.org.eg

43- Sout Al-Omma (2018): Business file of the private stadiums, 26 January. https: //soutalomma.com

44- Tarek Abdel Aal Hammad (2007): Corporate Governance, Ain Shams University, Cairo.

45- Waddah Mohammed Jassim (2018): A media plan to face the risks in the Faculty of Physical Education and Sports Science at the University of Baghdad, an unpublished Master Thesis, Department of Physical Management, Faculty of Physical Education for Girls, Alexandria University.

46- World Health Organization (2018): Global Strategy for Diet and Physical

Activity, World Health Assembly.

https://m.youm7.com/story/2018/12/6/4057948.

https://www.masrawy.com .

https://www.elfagr.com/336.

https://m.youm7.com/story/22.

http://www.cipe-arabia.orglindex.phplthemesldemocratic-governancel117governanceinthe21century $2003 \mathrm{p} 1$. 